\title{
Impact Testing of \\ Centrifugally Cast Canisters of Simulated Waste Glass
}

M. E. Peterson

J. M. Alzheimer

October 1984

Prepared for the U.S. Department of Energy under Contract DE-AC06-76RLO 1830

Pacific Northwest Laboratory Operated for the U.S. Department of Energy by Battelle Memorial Institute 


\title{
DISCLAIMER
}

This report was prepared as an account of work sponsored by an agency of the United States Government. Neither the United States Government nor any agency thereof, nor any of their employees, makes any warranty, express or implied, or assumes any legal liability or responsibility for the accuracy, completeness, or usefulness of any information, apparatus, product, or process disclosed, or represents that its use would not infringe privately owned rights. Reference herein to any specific commercial product, process, or service by trade name, trademark, manufacturer, or otherwise, does not necessarily constitute or imply its endorsement, recommendation, or favoring by the United States Government or any agency thereof. The views and opinions of authors expressed herein do not necessarily state or reflect those of the United States Government or any agency thereof.

\author{
PACIFIC NORTHWEST LABORATORY \\ operated by \\ BATTELLE \\ for the \\ UNITED STATES DEPARTMENT OF ENERGY \\ under Contract DE-AC06-76RLO 1830
}

\begin{tabular}{|c|c|}
\hline \multicolumn{2}{|c|}{$\begin{array}{l}\text { Printed in the United States of America } \\
\text { Available from } \\
\text { National Technical Information Service } \\
\text { United States Department of Commerce } \\
5285 \text { Port Royal Road } \\
\text { Springfield, Virginia } 22161\end{array}$} \\
\hline \multicolumn{2}{|c|}{$\begin{array}{l}\text { NTIS Price Codes } \\
\text { Microfiche A01 }\end{array}$} \\
\hline \multicolumn{2}{|c|}{ Printed Copy } \\
\hline Pages & $\begin{array}{l}\text { Price } \\
\text { Codes }\end{array}$ \\
\hline $001-025$ & $\mathrm{~A} 02$ \\
\hline $026-050$ & $A 03$ \\
\hline $051-075$ & A04 \\
\hline $076-100$ & $\mathrm{~A} 05$ \\
\hline $101-125$ & $A 06$ \\
\hline $126-150$ & $\mathrm{~A} 07$ \\
\hline $151-175$ & A08 \\
\hline $176-200$ & $A 09$ \\
\hline $201-225$ & A010 \\
\hline $226-250$ & A011 \\
\hline $251-275$ & A012 \\
\hline $276-300$ & A013 \\
\hline
\end{tabular}




\section{6}

IMPACT TESTING OF CENTRIFUGALLY CAST CANISTERS OF SIMULATED WASTE GLASS

M. E. Peterson

J. M. Alzheimer

October 1984

Prepared for the U.S. Department of Energy under Contract DE-ACD6-76RLO 1830

Pacific Northwest Laboratory

Richland, Washington 99352 

SUMMARY

Four simulated high-level waste canisters supplied by EG\&G Idaho, Inc. of Idaho Falls, Idaho, were subjected to impact tests at the Pacific Northwest Laboratory in Richland, Washington. The canister design was similar to the most recent Savannah River Laboratory (SRL) reference design for the Defense Waste Processing Facility. Three of the canister bodies were fabricated out of a special cast alloy (the centrifugally cast equivalent of 304L Stainless Steel). These were nonradioactive versions of canisters that can be fabricated by recycling slightly contaminated stainless steel. A canister of wrought $304 \mathrm{~L}$ Stainless Steel was also tested as a control. The canisters were filled with a borosilicate glass at SRL. The purpose of the test was to evaluate the effect of impacts on the canisters and provide input for a study to determine if slightly contaminated metal could be used for waste disposal canisters.

Each canister was subjected to three impacts. The first was a vertical drop from $30 \mathrm{ft}$ onto an unyielding surface with the bottom corner of the canister receiving the impact. The second was a horizontal drop from $4 \mathrm{D}$ in. onto a solid steel vertical cylinder ( $6 \mathrm{in}$. dia $\times 14 \mathrm{in.}$ long) in a puncture test. The final drop was from $30 \mathrm{ft}$ onto an unyielding surface with the fill nozzle and head receiving the impact. No rupturing of any of the canisters occurred as a result of the impacts. Strain circles were used to measure the surface strain in the impact areas. The maximum tensile strain experienced was $13 \%$ and the maximum compressive strain experienced was $16 \%$. These measured strains were below the minimum strain required for failure, which is at least $30 \%$. A helium leak test and liquid dye penetrant test were conducted on the weld regions of these canisters after the drop to evaluate the condition of the canister. No leaks were detected and no significant indications of cracks appeared. 



\section{ACXNOWLEDGMENTS}

This report was previously submitted to EG\&G Idaho, Inc. in partial fulfillment of Contract \#D1414 21876. The authors would like to thank S. C. Slate for his guidance in designing the test and preparing this document, K. E. Eliason and L. R. Shotwell for their technical assistance in test preparation and data collection, and PNL photography department for recording the test. 



\section{CONTENTS}

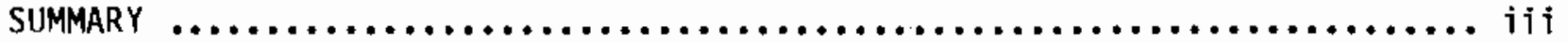

ACKNOWLEDGMENTS $\ldots \ldots \ldots \ldots \ldots \ldots \ldots \ldots \ldots \ldots \ldots \ldots \ldots \ldots \ldots \ldots \ldots \ldots \ldots \ldots \ldots$

1.0 INTRODUCTION $\ldots \ldots \ldots \ldots \ldots \ldots \ldots \ldots \ldots \ldots \ldots \ldots \ldots \ldots \ldots \ldots \ldots \ldots \ldots \ldots \ldots \ldots \ldots$

2.0 CONCLUSIONS AND RECOMMENDATIONS $\ldots \ldots \ldots \ldots \ldots \ldots \ldots \ldots \ldots \ldots \ldots \ldots \ldots \ldots$

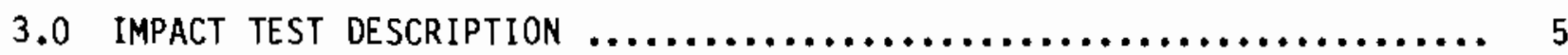

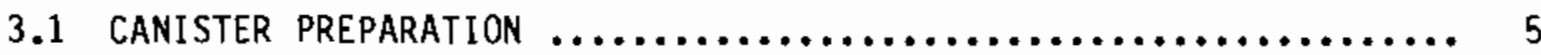

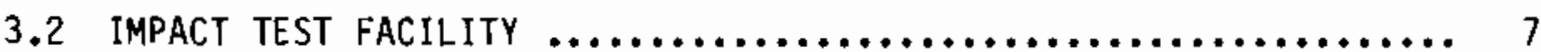

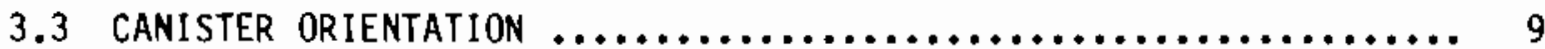

3.4 IMPACT TEST PROCEDURE $\ldots \ldots \ldots \ldots \ldots \ldots \ldots \ldots \ldots \ldots \ldots \ldots \ldots \ldots \ldots \ldots \ldots \ldots$

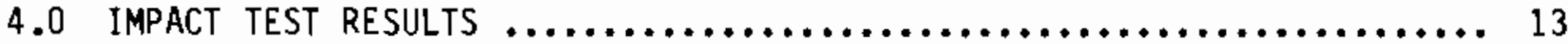

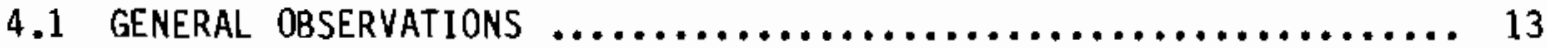

4.2 NONDESTRUCTIVE EXAMINATIONS $\ldots \ldots \ldots \ldots \ldots \ldots \ldots \ldots \ldots \ldots \ldots \ldots \ldots \ldots \ldots \ldots . \ldots \ldots$

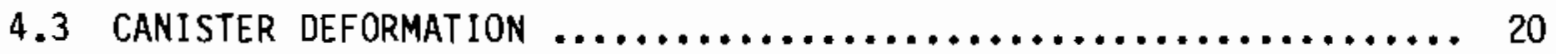

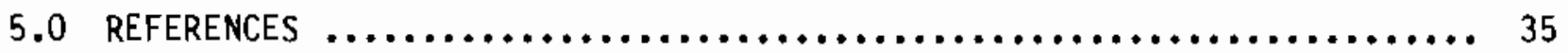




\section{FIGURES}

1 EG\&G Canister Design $\ldots \ldots \ldots \ldots \ldots \ldots \ldots \ldots \ldots \ldots \ldots \ldots \ldots \ldots \ldots \ldots \ldots \ldots$

2 Strain Circle Grid Used to Measure Surface Strain ................. 7

3 Canisters $\# 18$ and $\# 20$ Before Impact Testing $\ldots \ldots \ldots \ldots \ldots \ldots \ldots \ldots \ldots \ldots 8$

4 Canisters $\# 19$ and $\# 21$ Before Impact Testing ................... 8

5 Impact Pad Used in Testing $\ldots \ldots \ldots \ldots \ldots \ldots \ldots \ldots \ldots \ldots \ldots \ldots \ldots \ldots \ldots$

6 Bottom of Canister 18 After Impact $\ldots \ldots \ldots \ldots \ldots \ldots \ldots \ldots \ldots \ldots \ldots \ldots$

7 Mid-Line of Canister \#18 After Impact $\ldots \ldots \ldots \ldots \ldots \ldots \ldots \ldots \ldots \ldots \ldots$

8 Nozzle Region of Canister \#18 After Impact ..................... 14

9 Bottom of Canister $\# 19$ After Impact $\ldots \ldots \ldots \ldots \ldots \ldots \ldots \ldots \ldots \ldots \ldots \ldots$

10 Mid-Line of Canister $\# 19$ After Impact $\ldots \ldots \ldots \ldots \ldots \ldots \ldots \ldots \ldots \ldots \ldots \ldots$

11 Nozzle Region of Canister \#19 After Impact $\ldots \ldots \ldots \ldots \ldots \ldots \ldots \ldots \ldots \ldots$

12 Botton of Canister \#20 After Impact $\ldots \ldots \ldots \ldots \ldots \ldots \ldots \ldots \ldots \ldots \ldots \ldots$

13 Mid-Line of Canister $\$ 20$ After lmpact $\ldots \ldots \ldots \ldots \ldots \ldots \ldots \ldots \ldots \ldots \ldots \ldots$

14 Nozzle Region of Canister \#20 After Impact $\ldots \ldots \ldots \ldots \ldots \ldots \ldots \ldots \ldots \ldots 17$

15 Bottom of Canister \#21 After Impact $\ldots \ldots \ldots \ldots \ldots \ldots \ldots \ldots \ldots \ldots \ldots \ldots$

16 Mid-Line of Canister \#21 After lmpact $\ldots \ldots \ldots \ldots \ldots \ldots \ldots \ldots \ldots \ldots \ldots$

17 Nozzle Region of Canister \#21 After Impact $\ldots \ldots \ldots \ldots \ldots \ldots \ldots \ldots \ldots \ldots$

18 Set-Up for Helium Leak Test $\ldots \ldots \ldots \ldots \ldots \ldots \ldots \ldots \ldots \ldots \ldots \ldots \ldots \ldots \ldots$

19 Surface Strain Along Axial Trace for Canister \#18

Bottom Drop ........................................ 22

20 Surface Strain Along Axial Trace for Canister \#19

Bottom Drop ......................................... 22

21 Surface Strain Along Axial Trace for Canister \#20

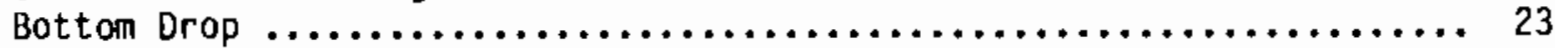

22 Surface Strain Along Axial Trace for Canister \$21

Bottom Drop ........................................ 23 
23 Surface Strain Along Axial Trace for Canister \#18

Side Drop .............................................. 25

24 Surface Strain Along Circumferential Trace for Canister \#19

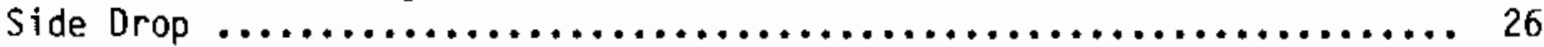

25 Surface Strain Along Circumferential Trace for Canister \#2D

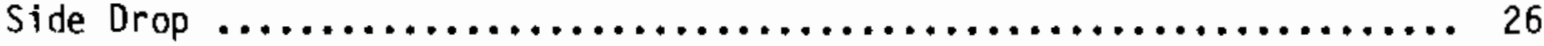

26 Surface Strain Along Axial Trace for Canister \#20

Side Drop $\ldots \ldots \ldots \ldots \ldots \ldots \ldots \ldots \ldots \ldots \ldots \ldots \ldots \ldots \ldots \ldots \ldots \ldots, 27$

27 Surface Strain Along Axial Trace for Canister \#21

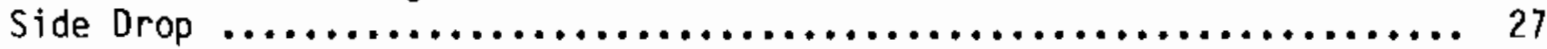

28 Surface Strain Along Axial Trace for Canister \#18

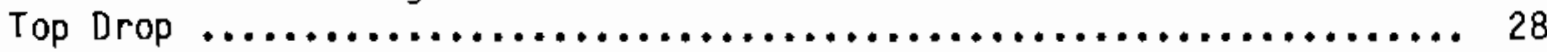

29 Surface Strain Along Axial Trace for Canister \#19

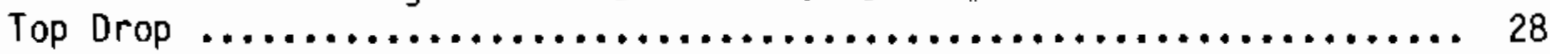

30 Surface strain Along Axial Trace for Canister \#20

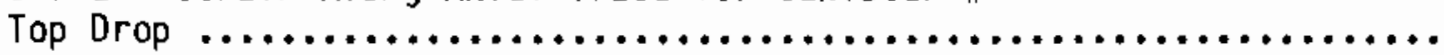

31 Surface Strain Along Axial Trace for Canister \#21

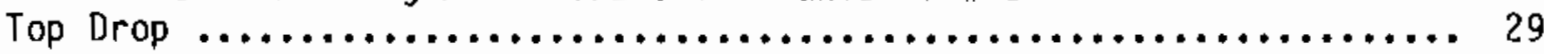

32 Shape of the Nozzle of Canister $\# 18 \ldots \ldots \ldots \ldots \ldots \ldots \ldots \ldots \ldots \ldots, 30$

33 Shape of the Bottom of Canister $\# 18 \ldots \ldots \ldots \ldots \ldots \ldots \ldots \ldots \ldots \ldots, 30$

34 Shape of the Nozzle of Canister $\# 19 \ldots \ldots \ldots \ldots \ldots \ldots \ldots \ldots \ldots \ldots \ldots, 31$

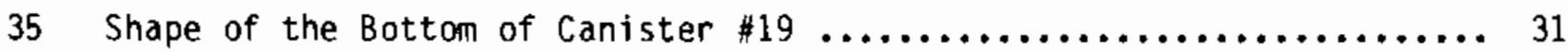

36 Shape of the Nozzle of Canister $\# 20 \ldots \ldots \ldots \ldots \ldots \ldots \ldots \ldots \ldots \ldots \ldots, 32$

37 Shape of the Bottom of Canister $\$ 20 \ldots \ldots \ldots \ldots \ldots \ldots \ldots \ldots \ldots \ldots . . . \ldots \ldots$

38 Shape of the Nozzle of Canister $\# 21 \ldots \ldots \ldots \ldots \ldots \ldots \ldots \ldots \ldots \ldots \ldots \ldots, 33$

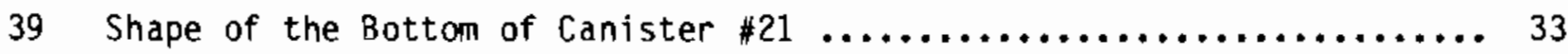





\subsection{INTRODUCTION}

Impact tests on full-scale canisters filled with simulated high-level waste glass were conducted to demonstrate that accidental impacts would not create a hole that would allow leakage at a rate greater than $10^{-5} \mathrm{~atm} \mathrm{cc} / \mathrm{s}$. Both tests and analyses are needed to show that the proposed accident environments are not severe enough to alter the basic integrity of standard canisters. The results from the impact tests are required for input into safety studies on the transporting and handling of high-level waste (HLW) canisters.

The Pacific Northwest Laboratory (PNL) conducted impact tests on full-size canisters containing simulated HLW in 1975, 1977, 1981, and 1983. Canisters have been dropped from heights ranging from $40 \mathrm{in}$. to $104 \mathrm{ft}$ in different orientations to evaluate the best design for canister end pieces, fill nozzles, welds, and closure lids. The current designs for canisters were based, in part, on these test results and these designs have proved to be resistant to rupture during impacts. Detailed evaluation of the damage to the glass has also been performed.

The purpose of this specific test program was to measure the effects of impacts on special canisters fabricated in Idaho Falls by EG\&G Idaho, Inc. for possible use in the Defense Waste Processing Facility (DWPF). Special focus was put on the canister body, which was fabricated from a cast alloy equivalent to $304 \mathrm{~L}$ stainless steel. One wrought canister and three centrifugally cast canisters were tested. After testing, the nozzles were removed and sent to Savannah River Laboratory (SRL) and the canister bodies were returned to EG\&G. In addition to this report, a video tape documents the impact tests. 



\subsection{CONCLUSIONS AND RECOMMENDATIONS}

To accurately evaluate the impact performance of canisters, tests were made using full-scale canisters containing simulated wastes. This test produced data from which the following conclusions were made.

- Canisters fabricated from special cast alloys can withstand the same impact conditions that have been used on the DWPF reference canister.

- Based on visual inspection, helium leak tests, and liquid dye penetrant tests, all four canisters were leak tight and no significant indications of cracks resulted from the impacts.

- Based on surface strain measurements using the strain circles, rupture would not occur without considerably more stress.

- Because of the limited number of tests and the exclusion of glass fines evaluation, further testing is necessary if these canisters are to be used for DWPF waste glass. 



\subsection{IMPACT TEST DESCRIPTION}

This report divides the EG\&G impact test into two sections: Impact Test Description and Impact Test Results. The impact test description discusses the canister preparation, the impact test facility, the canister orientations and the impact test procedure. The procedure used for impact testing has been developed and standardized through past testing programs.

\subsection{CANISTER PREPARATION}

EG\&G supplied to PNL one wrought canister and three centrifugally cast canisters. In general, the canisters were fabricated according to the SRL reference design shown in Figure 1 for the DWPF (Baxter 1983). The centrifugally cast canisters had a center weld that resulted from the casting equipment used at this time. The canisters were filled with borosilicate glass at SRL at DWPF reference conditions (Baxter 1983). The canisters were designated $\# 18, \# 19, \# 20$ and \#21 when they arrived at PNL. Canister \#18 was the wrought canister.

Physical measurements of the weight, length, diameter and center of gravity were made for each canister. These measurements are listed in Table 1. In addition, the shape of the canister was recorded in two ways. First, profile tracings of both the nozzle region and the bottom region were made. This was done by bending a flexible metal tape to the shape of the canister and tracing the shape on paper. The second method was to record diameter measurements at six inch intervals along the canister body. The shape measurements were repeated after the impact tests.

Strain circles were placed on the canisters in the impact area of the nozzle, mid-line, and bottom regions. By measuring the circle diameters before and after the drops, the surface strains in the impact areas can be determined within $2 \%$ accuracy. The initial circle diameters were nominally $0.20 \mathrm{in}$, and were arranged in a rectangular grid $0.25 \mathrm{in}$. from center to center. Each row and column of the grid was identified with a letter or number for reference. Figure 2 shows the strain circle grid. Strain circles were used instead of 


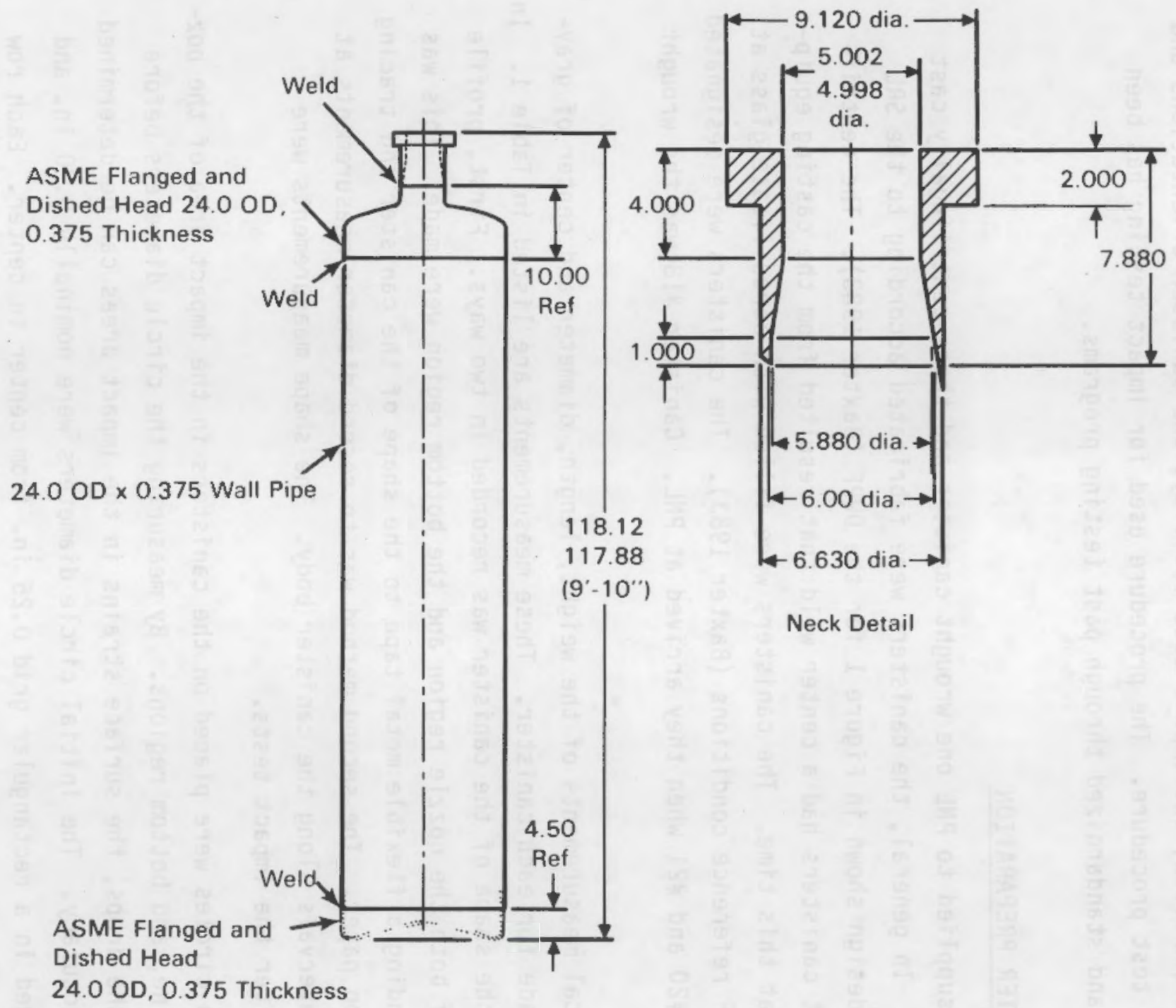

Canister Assembly

FIGURE 1. EG\&G Canister Design 


\section{TABLE 1. Physical Measurements of the Canisters}

\begin{tabular}{|c|c|c|c|c|c|}
\hline $\begin{array}{c}\text { Canister } \\
\text { No. } \\
\end{array}$ & $\begin{array}{c}\text { EG\&G } \\
\text { Reference } \\
\end{array}$ & $\begin{array}{l}\text { Weight, } \\
1 \mathrm{~b} \\
\end{array}$ & $\begin{array}{c}\text { Di ameter, } \\
\text { in. }\end{array}$ & $\begin{array}{c}\text { Length, } \\
\text { in. }\end{array}$ & $\begin{array}{l}\text { Distance from } \\
\text { Bottom to Center } \\
\text { of Gravity, in. }\end{array}$ \\
\hline 18 & $\# 008$ & 4335 & 24 & 118.00 & 44.38 \\
\hline 19 & \#011 & 4328 & 24 & 118.56 & 46.00 \\
\hline 20 & $\# 012$ & 4280 & 24 & 118.63 & 46.44 \\
\hline 21 & $\# 003$ & 4600 & 24 & 117.81 & 46.25 \\
\hline
\end{tabular}

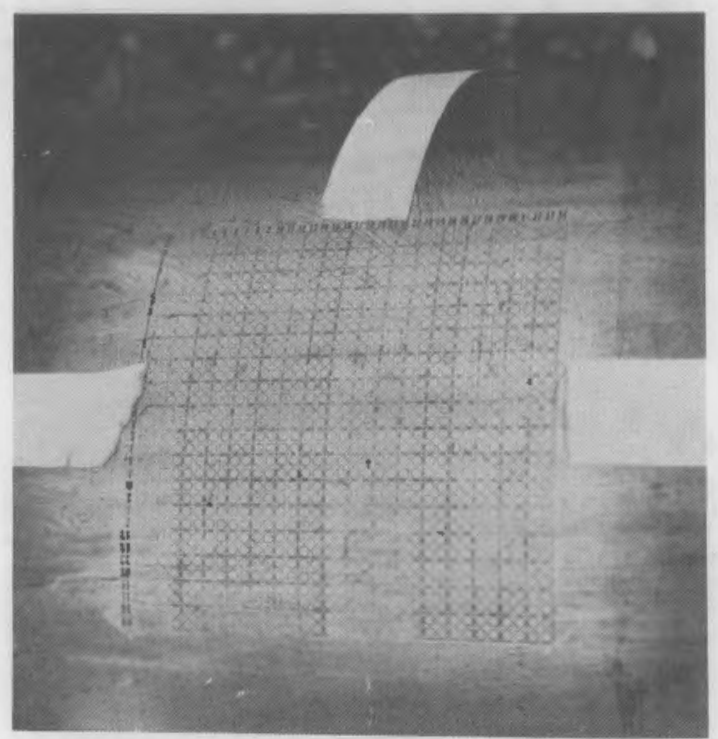

FIGURE 2. Strain Circle Grid Used to Measure Surface Strain

strain gauges because the strain circles are simple to use, can cover a large area, are relatively inexpensive, and are accurate to within $2 \%$. The canisters before impact testing are shown in Figures 3 and 4 .

\subsection{IMPACT TEST FACILITY}

A truck-mounted crane was used to hoist the canisters the specified distance above the impact pad. A conventional cable choker was fastened around each canister and positioned so as to achieve the desired vertical and horizontal orientation of the canister. The cable choker was attached to the 


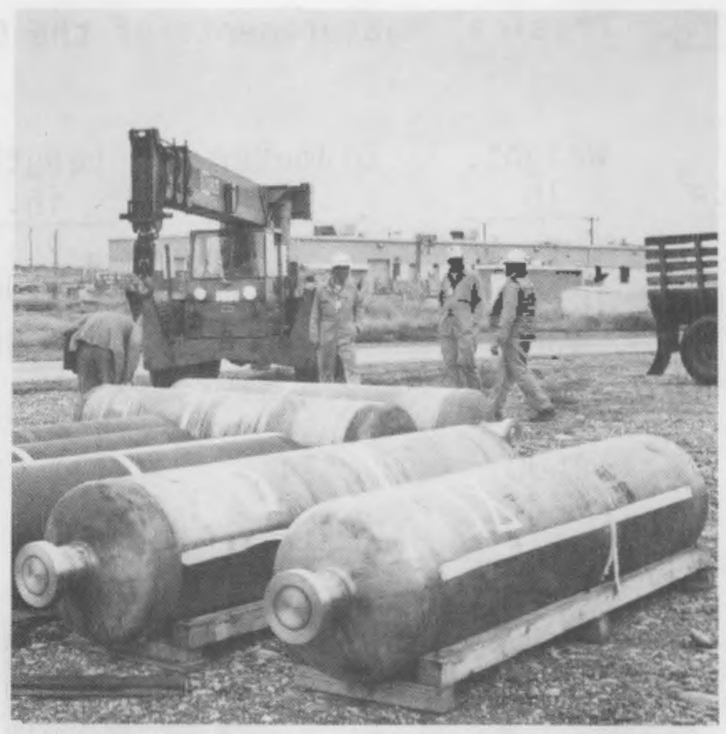

FIGURE 3. Canisters \#18 and \#20 Before Impact Testing

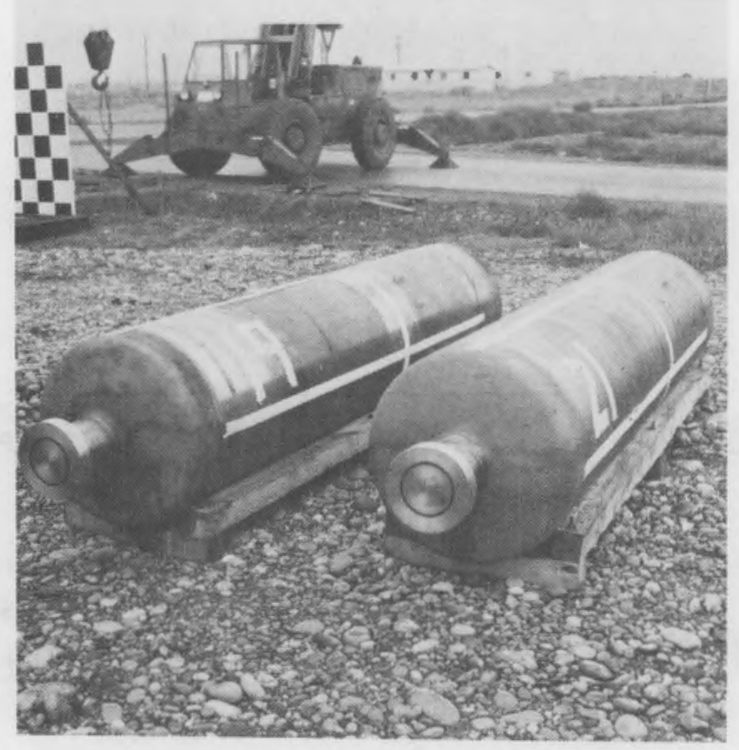

FIGURE 4. Canisters \#19 and \#21 Before Impact Testing 
lifting cable by a latching hook that could be released by a lanyard from the ground. This drop technique allowed good position control so the canister could be made to impact in any desired orientation. A rope, loosely taped to the lowest point of the canister to measure the drop height, was pulled loose after the canister was raised to the desired height.

The impact pad consisted of a $10 \mathrm{ft}$ by $10 \mathrm{ft}$ by $4 \mathrm{ft}$ thick slab of reinforced concrete with $5 \mathrm{ft}$ by $7 \mathrm{ft}$ by $7 \mathrm{in}$. thick steel plate on top. The mass of the pad was approximately 10 times the mass of a single canister which satisfies guidelines for an unyielding surface. For the puncture test, the canisters were dropped on a solid steel vertical cylinder ( 6 in. dia by 14 in. high) that was bolted onto the steel plate. Behind the impact pad was a checkerboard pattern backdrop that was used in conjunction with high-speed photography for estimating distances during the moment of impact. The checkerboard squares were $1 \mathrm{ft}$ by $1 \mathrm{ft}$. The backdrop and impact pad are shown in Figure 5 .

\section{CANISTER ORIENTATION}

The canisters were dropped at the orientations recognized at this time as creating the most stress on the canister design. Because the cast alloy was used on the canister body, special focus was placed on orientations that would

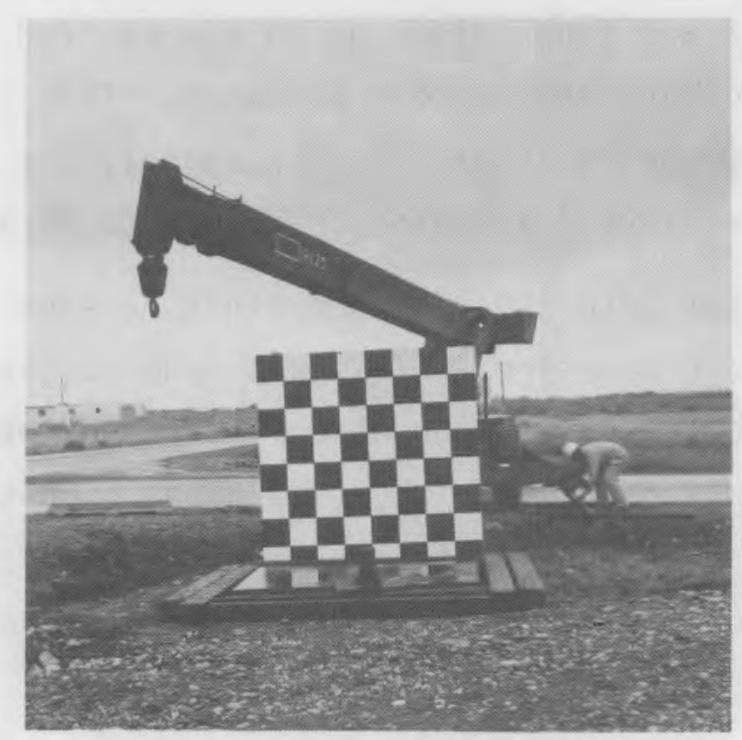

FIGURE 5. Impact Pad Used in Testing 
affect the canister body. Each canister was dropped three times: from $30 \mathrm{ft}$ onto the bottom corner, from $40 \mathrm{in}$. onto the side in a puncture test, and from $30 \mathrm{ft}$ onto the fill nozzle. The first drop for each canister was from $30 \mathrm{ft}$ with the center of gravity over the bottom corner to test the joint between the bottom and body of the canister. The second drop was horizontally from 40 in. onto a 6 in. diameter solid steel cylinder with the center of gravity over the impact point to test the strain resistance of the alloy. The third drop was from $30 \mathrm{ft}$ onto the fill nozzle of the canister with the center of gravity located over a different point on the head for each canister to determine strain levels in the top. The location of the center of gravity for the top drop was varied to evaluate the most severe orientation. The top drop did not directly affect the body of the canister but was important in the overall evaluation of the canister performance. The above order of canister drops was done in accordance with the Code of Federal Regulations (Volume 10, Part 71, Appendix B). Table 2 shows the impact orientation for each canister. If future tests reveal that other orientations create a more severe impact, additional impact tests would be required.

\section{IMPACT TEST PROCEDURE}

In aligning the canister for each test, a conventional cable choker was fastened to the canister and adjusted until the correct drop angle was achieved. The canister was then raised up to the desired drop height using a premeasured rope to indicate the correct distance. This rope was then pulled loose prior to dropping the canister. Upon a signal, the latching hook was released by pulling the lanyard allowing the canister to drop.

The wrought canister (\#18) was dropped first in each orientation followed by the centrifugally cast canisters. This was done so that an immediate comparison could be made between the wrought canister and the centrifugally cast canisters. Each drop was recorded with video tape, high-speed film, and still photographs. Photographs of the canisters were taken before and after the impact. Using high-speed $\mathrm{film}$, the correct orientation for each drop was confirmed. 
TABLE 2. Summary of Canister Orientations During Impact Tests

\begin{tabular}{|c|c|c|}
\hline $\begin{array}{c}\text { Canister } \\
\text { No. } \\
\end{array}$ & Impact Area & Angle (a) \\
\hline \multirow[t]{3}{*}{18} & Bottom & $15^{\circ}$ \\
\hline & Side & $90^{\circ}$ \\
\hline & Nozzle & $6^{\circ}$ \\
\hline \multirow[t]{3}{*}{19} & Bottom & $15^{\circ}$ \\
\hline & Side & $90^{\circ}$ \\
\hline & Nozzle & $4^{\circ}$ \\
\hline \multirow[t]{3}{*}{20} & Bottom & $13^{\circ}$ \\
\hline & Side & $90^{\circ}$ \\
\hline & Nozzle & $9^{\circ}$ \\
\hline \multirow[t]{3}{*}{21} & Bottom & $13^{\circ}$ \\
\hline & Side & $90^{\circ}$ \\
\hline & Nozzle & $0^{\circ}$ \\
\hline
\end{tabular}

(a) Angle as measured from the vertical axis. This angle was calculated such that the center of gravity was located over the desired impact point.

After impact testing, the canisters were transported to separate facilities for the nondestructive tests that included the helium leak test, dye penetrant test, and strain circle analysis. 



\subsection{IMPACT TEST RESULTS}

The impact test results include general observations, nondestructive examination results, and canister deformation measurements.

\subsection{GENERAL OBSERVATIONS}

A review of the high-speed film indicated that the desired orientations were achieved. No rupture occurred as a result of any of the impacts. With all but two of the drops, the canister impacted, rebounded and hit again. In the two exceptions, the canisters impacted with no rebound. After all drops, the canisters were immediately visually examined. Canister \#18, \#19, and \#20 had a similiar type of deformation on the bottom region; the weld and metal stretched during impact forming a single bulge. With canister \#21, the canister body and dished bottom bulged out with the weld appearing unchanged. The deformation of the nozzle region and mid-line region of the canister was similiar for each orientation. The canisters are shown after impact in Figures 6 through 17. After the drop tests, the canisters underwent nondestructive examinations in the form of a helium leak test and liquid dye penetrant test.

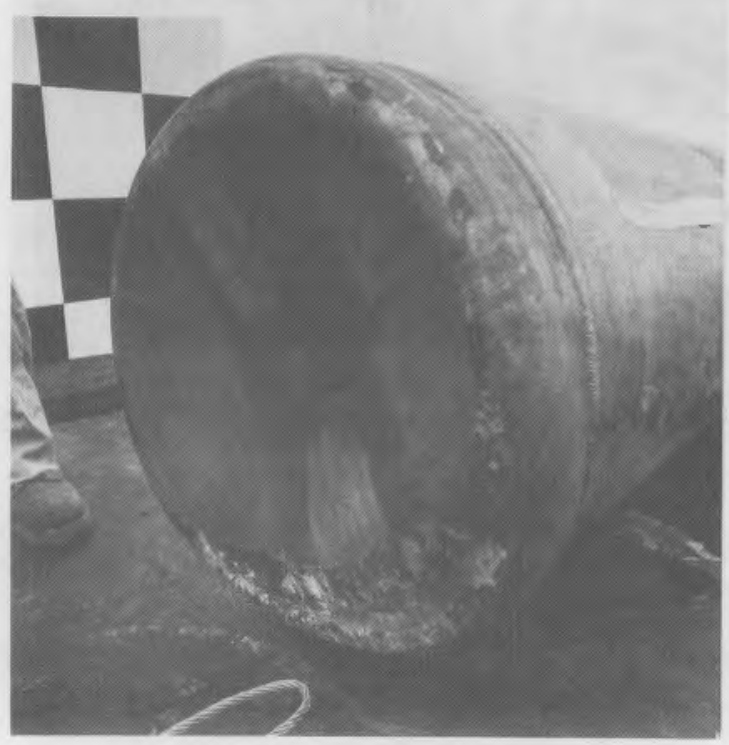

FIGURE 6. Bottom of Canister \#18 After Impact 


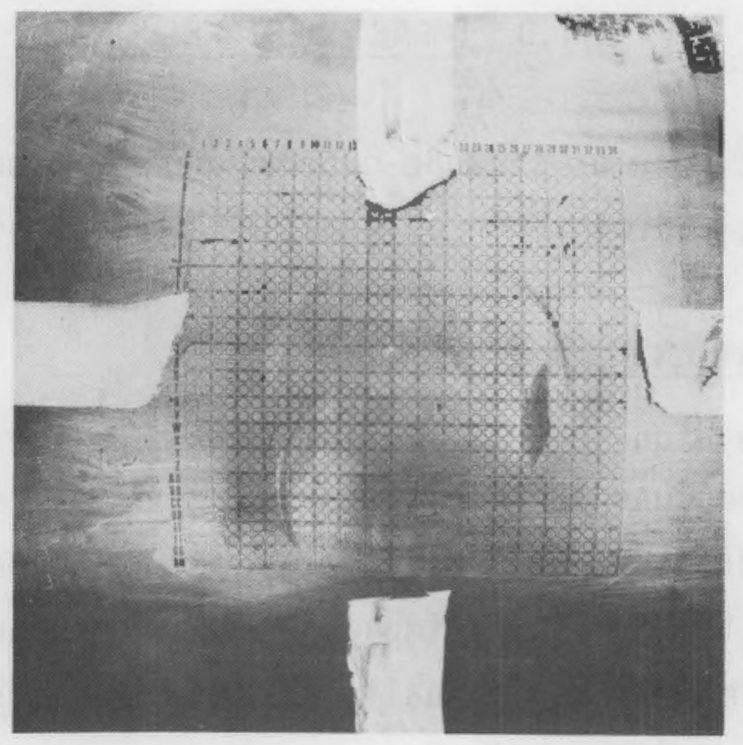

FIGURE 7. Mid-Line of Canister \#18 After Impact

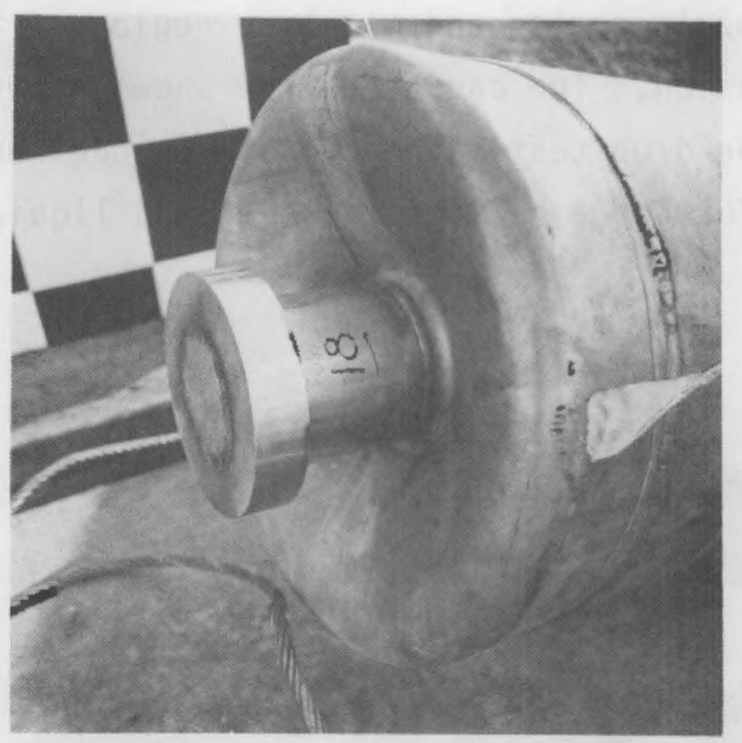

FIGURE 8. Nozzle Region of Canister \#18 After Impact 


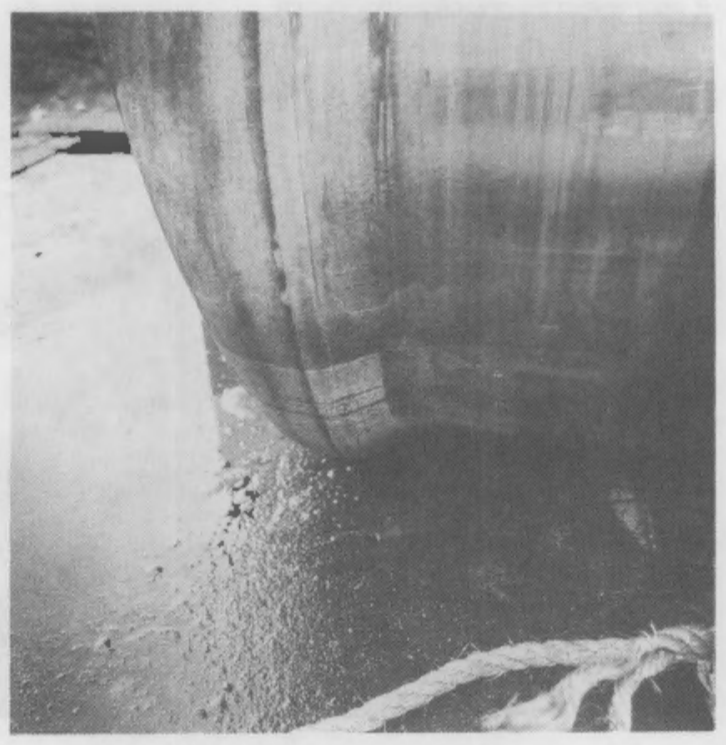

FIGURE 9. Bottom of Canister \#19 After Impact

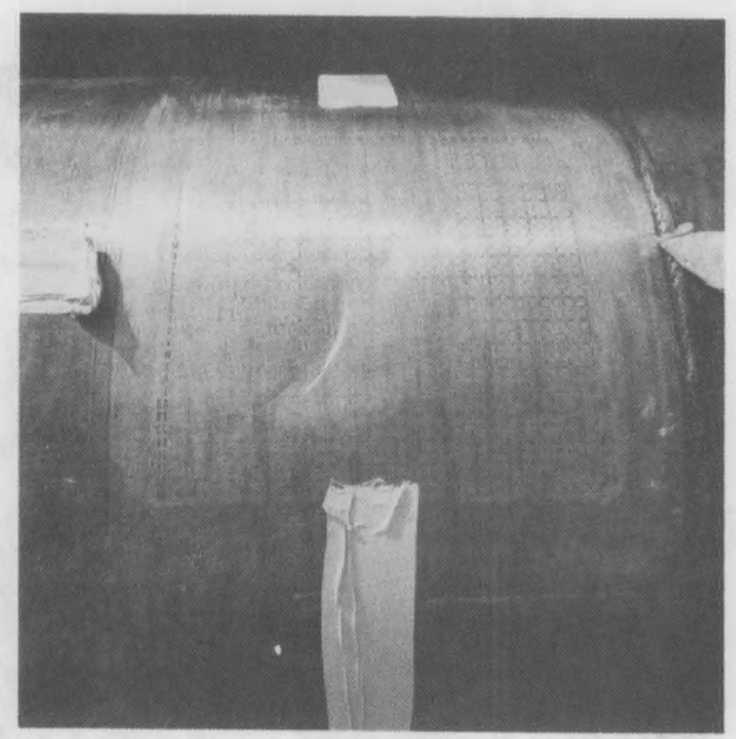

FIGURE 10. Mid-Line of Canister \#19 After Impact 


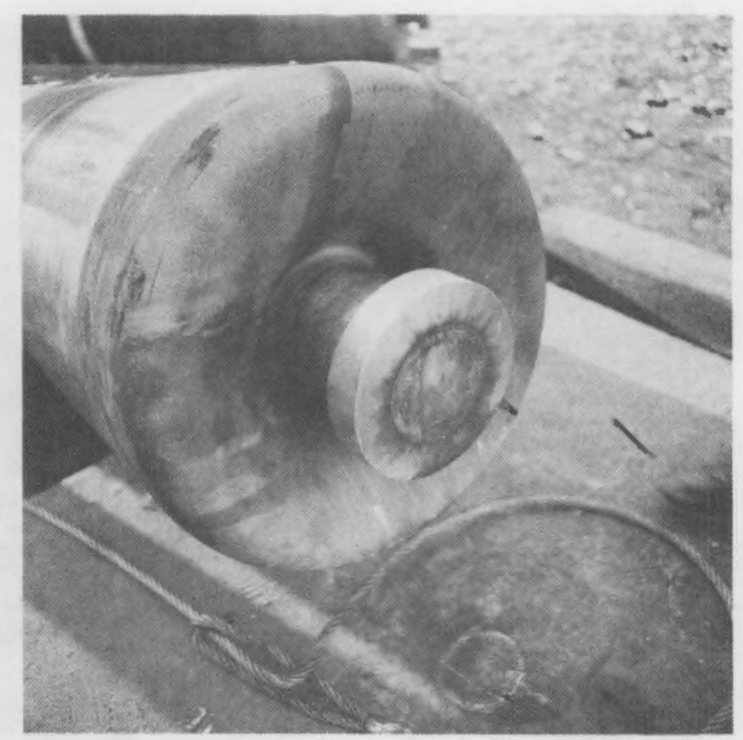

FIGURE 11. Nozzle Region of Canister \#19 After Impact

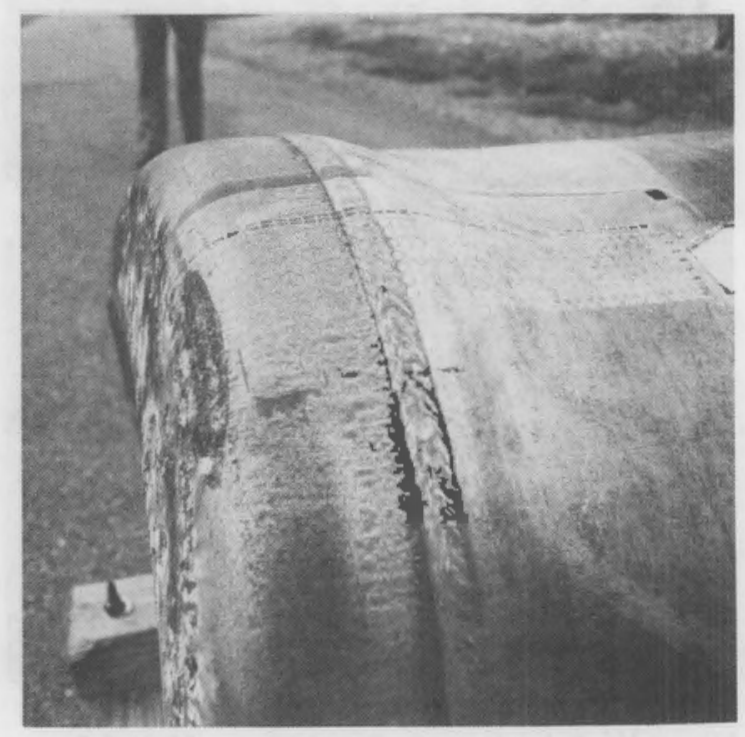

FIGURE 12. Bottom of Canister \#20 After Impact 


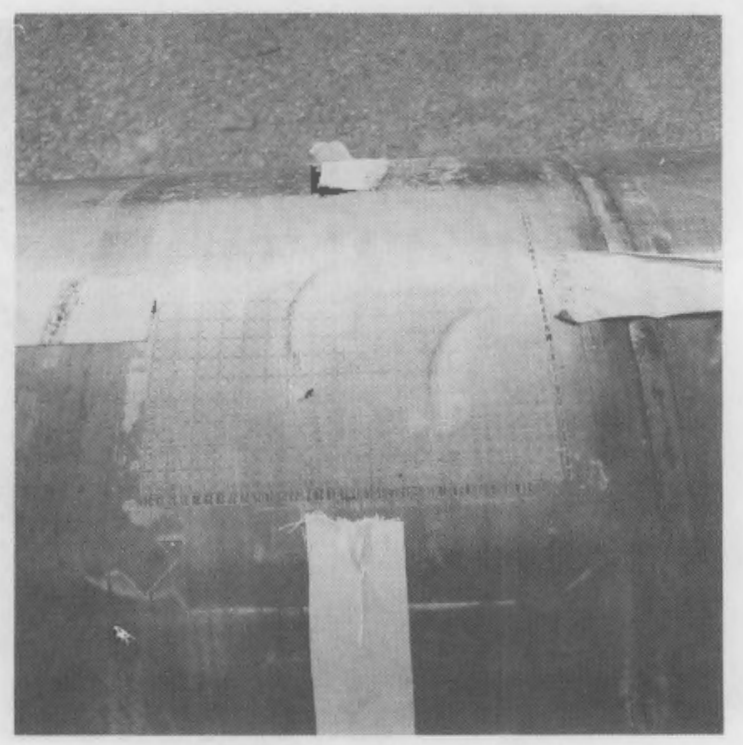

FIGURE 13. Mid-Line of Canister \#20 After Impact

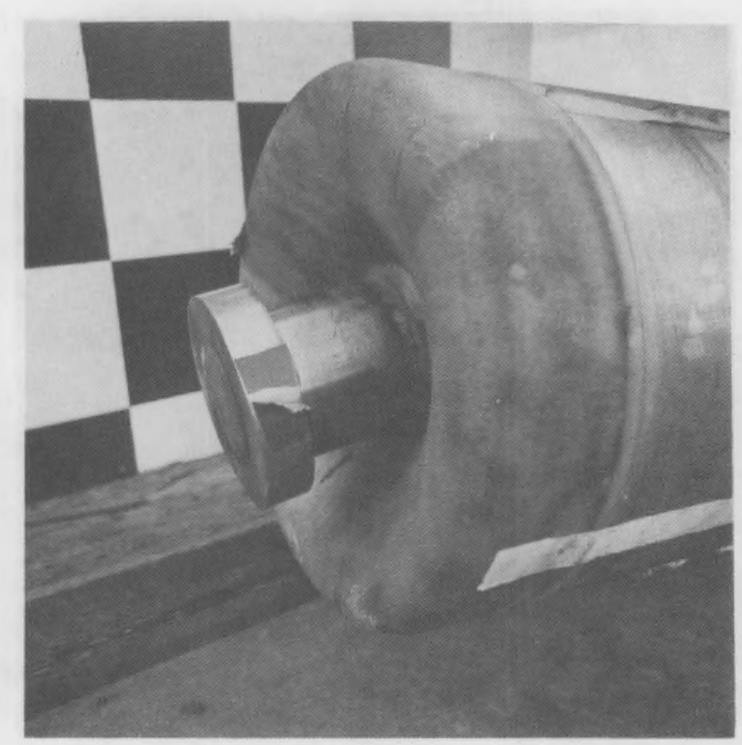

FIGURE 14. Nozzle Region of Canister \#20 After Impact 


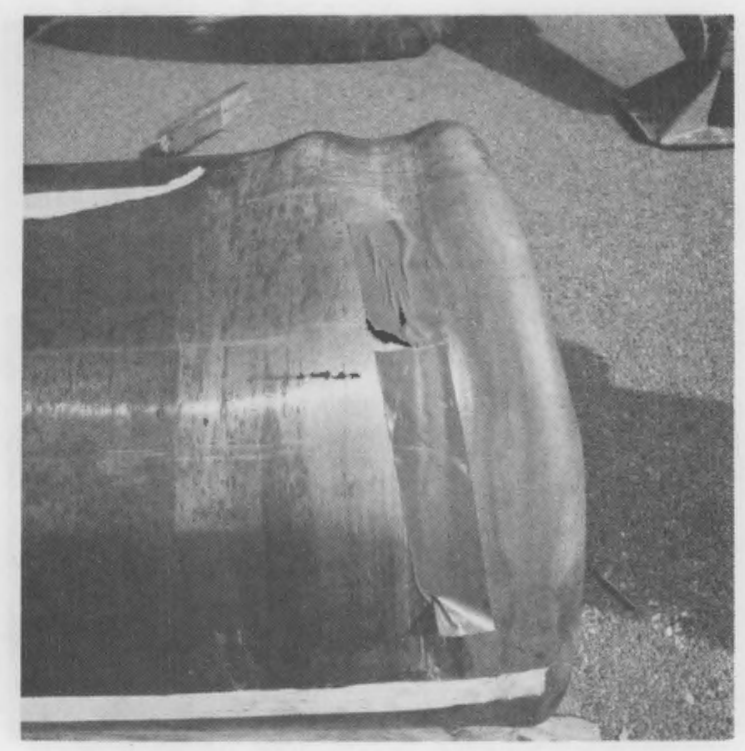

FIGURE 15. Bottom of Canister \#21 After Impact

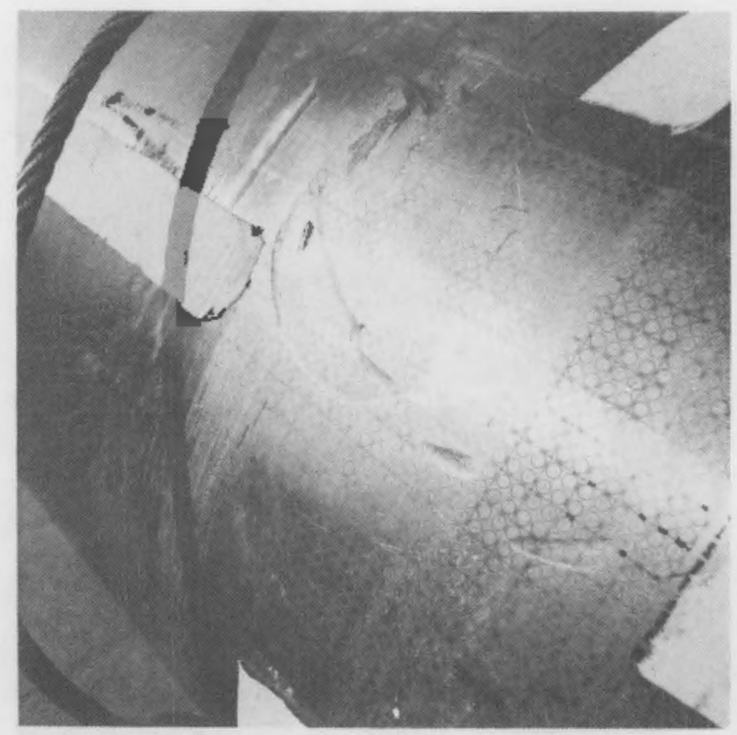

FIGURE 16. Mid-Line of Canister \#21 After Impact 


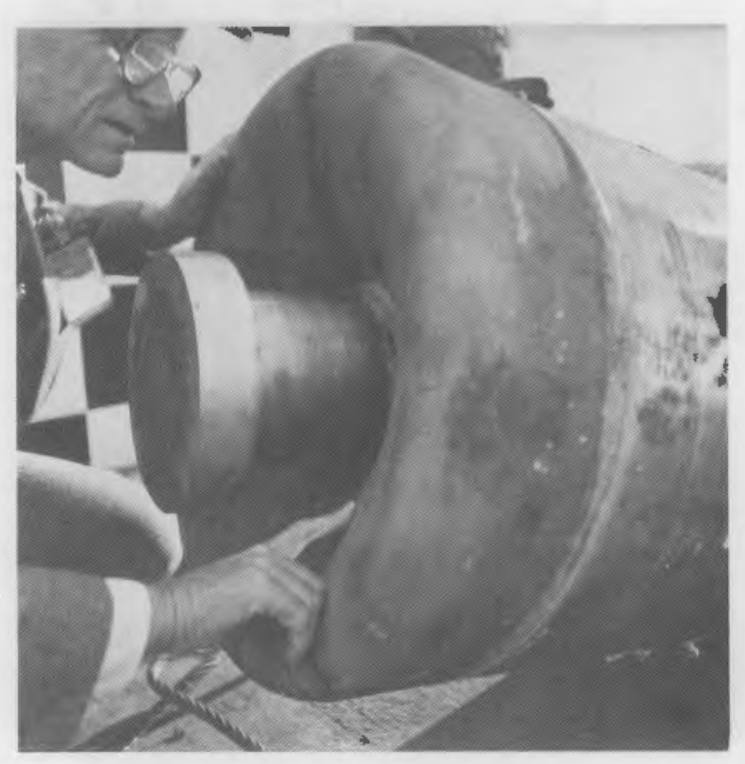

FIGURE 17. Nozzle Region of Canister \#21 After Impact

\subsection{NONDESTRUCTIVE EXAMINATIONS}

All of the canisters were subjected to a helium leak test and dye penetrant test in accordance with procedures in ASME Section III and V. The purpose of these tests was to determine if the weld and impact area were leak tight and if any surface cracks existed.

For the helium leak test, which was performed first, heavy plastic was secured to the canister in all areas to be examined to isolate the area of interest from the atmosphere. Canister \#18 had plastic around the top and bottom because no center weld existed in this canister. Canisters \#19, \#20, and \#21 had plastic around the top, bottom and center weld. Air was evacuated from the canister and a standard helium leak rate of $2.2 \times 10^{-8} \mathrm{atin} \mathrm{cc} / \mathrm{sec}$ was put into the canister. This was then used to calibrate the mass spectrometer and determine its sensitivity. The instrument sensitivity was determined to be $\left(2.4 \times 10^{-10} \mathrm{~atm} \mathrm{cc} / \mathrm{sec}\right) / \mathrm{scale}$ division. Helium was then injected into the plastic around all regions and the instrument measured any helium that was to leak into the canister. No leaks greater than the instrument sensitivity were detected. A leak rate of $1 \times 10^{-5} \mathrm{~atm} \mathrm{cc} / \mathrm{sec}$ has been proposed as the acceptable level for transportation and final disposal. Figure 18 shows the set-up for the helium leak test. 


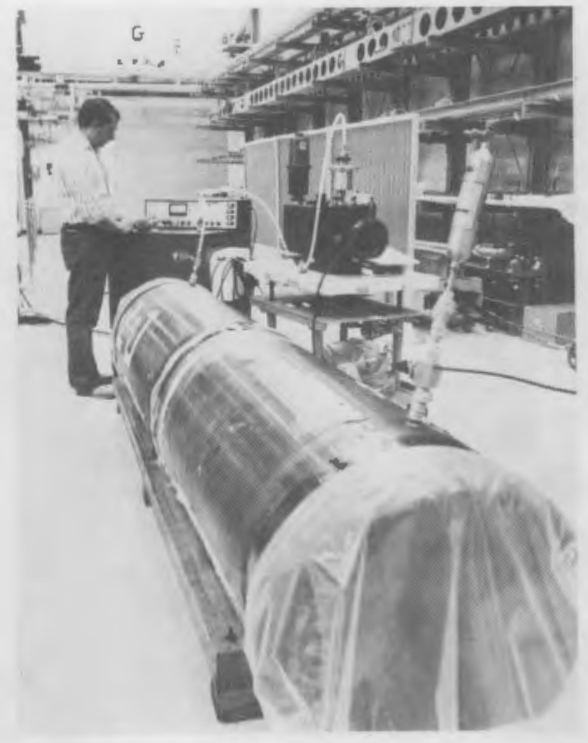

FIGURE 18. Set-Up for Helium Leak Test

The liquid dye penetrant test was used to examine the welds and surfaces on both sides of the welds to determine if surface cracks developed as a result of this impact. The first step of the procedure was to clean the area under examination with acetone and wipe it dry. A liquid penetrant was then brushed on the surface and was wiped off after remaining on the surface for at least 10 minutes. A developer was brushed on and after drying the results were visually determined. No indications of cracks were found on the canister areas examined.

\subsection{CANISTER DEFORMATION}

Canister deformation was measured with strain circles placed on the canister surface in the areas that were anticipated to experience high strain levels as a result of the various drop tests. By measuring the circle diameters before and after the impacts, the surface strains in the impact areas could be determined within $2 \%$ accuracy. The wrought $304 \mathrm{~L}$ stainless steel canister was used as a control in which the centrifugally cast canisters were compared.

In general, the deformations of all the canisters were very similiar with the exception of canister \#21 which deformed somewhat differently during the 
botton drop. The maximum absolute strains measured anywhere on the four canisters were $16 \%$ compressive and $13 \%$ tensile strains. A tensile strain of at least $30 \%$ for wrought $304 \mathrm{~L}$ stainless steel is reported as a minimum for failure to occur (Cubberly et al. 1978). While actual localized strains may have been slightly higher than those measured, a large margin existed between the drop test strains and the strains required to cause rupture of the canister wall due to ductility exhaustion. The results from these tests were similiar to the results obtained on SRL wrought stainless steel canisters in 1983. In those impact tests, the maximum absolute strains were $9 \%$ compressive and $14 \%$ tensile strains.(a)

The deformation of the bottom of Canister \#21 is shown in Figure 15 . The canister wall bulged out in two places to a distance of $0.88 \mathrm{in}$. from the weld. The deformation extended 6 in. up the canister wall from the weld. With Canister \#18, the canister wall bulged out to a distance of $0.88 \mathrm{in}$. from the weld and extended up the canister wall $3 \mathrm{in}$. from the weld. Canisters \#19 and \#20 also had a wall bulge $0.88 \mathrm{in}$. from the weld that extended up the canister wall 2 in. from the weld.

Figures 19 through 22 show the strains measured for the bottom drop tests. Each plot represents a trace of strains as measured along a line starting on the canister body and progressing across the body to the bottom weld and across the bottom. For the bottom impact, the zero on the horizontal axis represents a point on the bottom weld. The hoop direction corresponds to the direction going around the canister diameter. The axial direction corresponds to a line normal to the hoop direction and co-planar with the canister wall. Surface strains greater than zero are tensile strains while strains less than zero are compressive strains. In all cases, the measured strains resulting from the bottom impact were not large enough to suggest that rupture was imminent. The variations in the strain profiles for each canister were due to the location of the initial impact relative to the strain circle guide and due to the actual differences in the strain resulting from the impact.

(a) M. E. Petersen, J. M. Alzheimer, and S. C. Slate. 1984. Impact Testing of Simulated High-Level Waste Glass Canisters. PNL-5251. Pacific Northwest Laboratory, Richland, Washington (in press). 


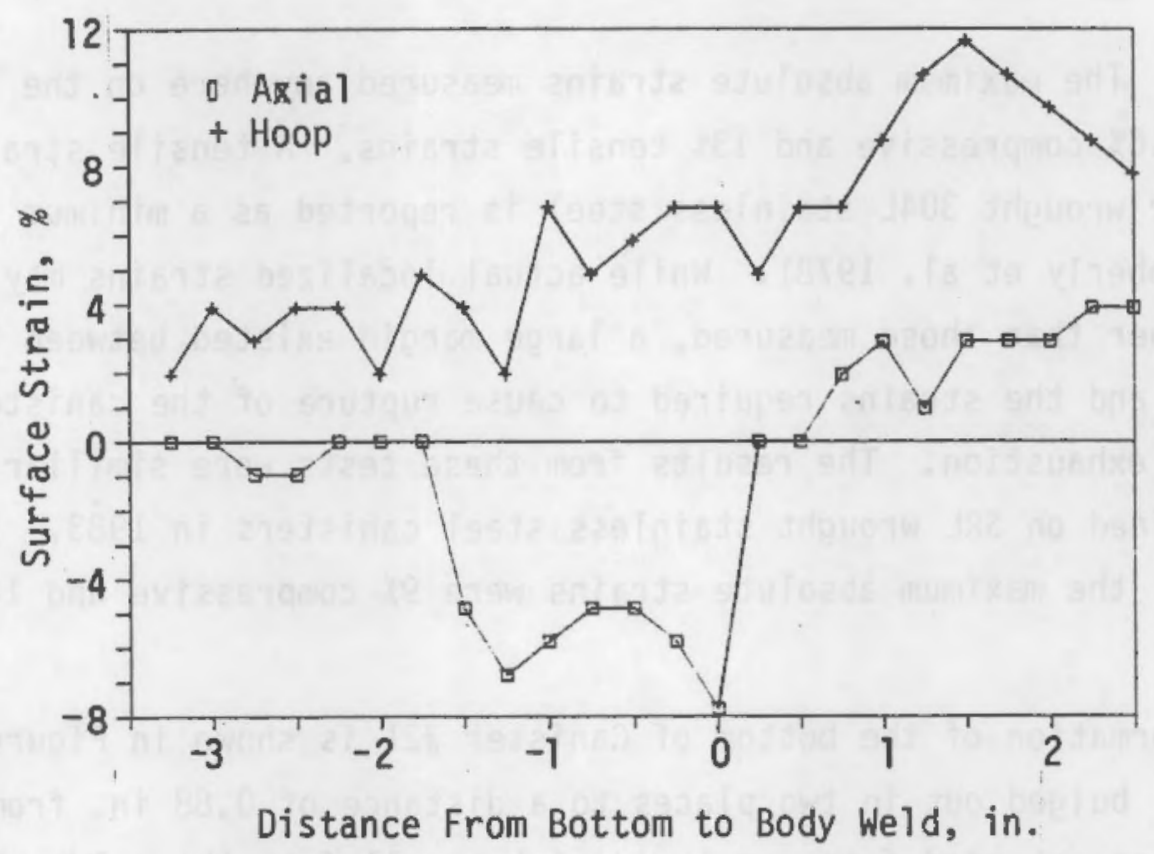

FIGURE 19. Surface Strain Along Axial Trace for Canister \#18 Bottom Drop

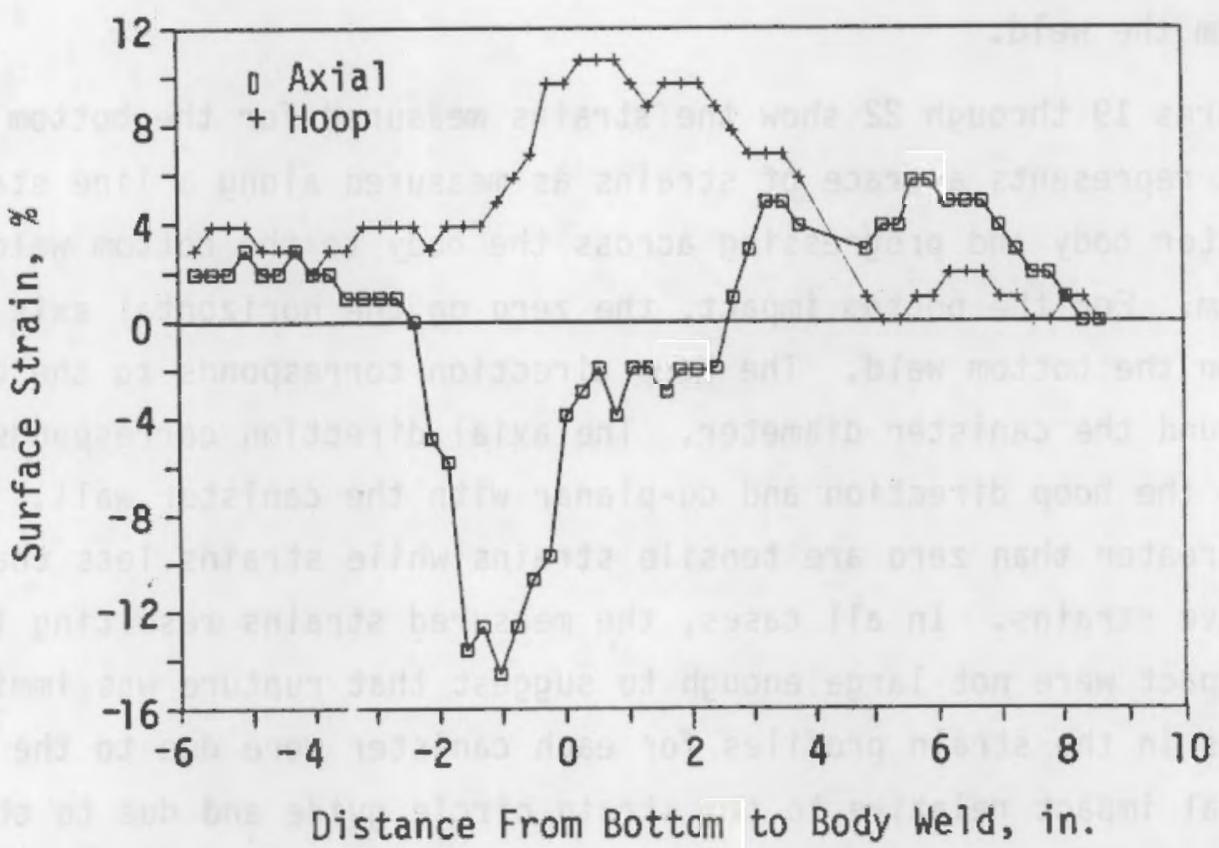

FIGURE 20. Surface Strain Along Axial Trace for Canister \#19 Bottom Drop 


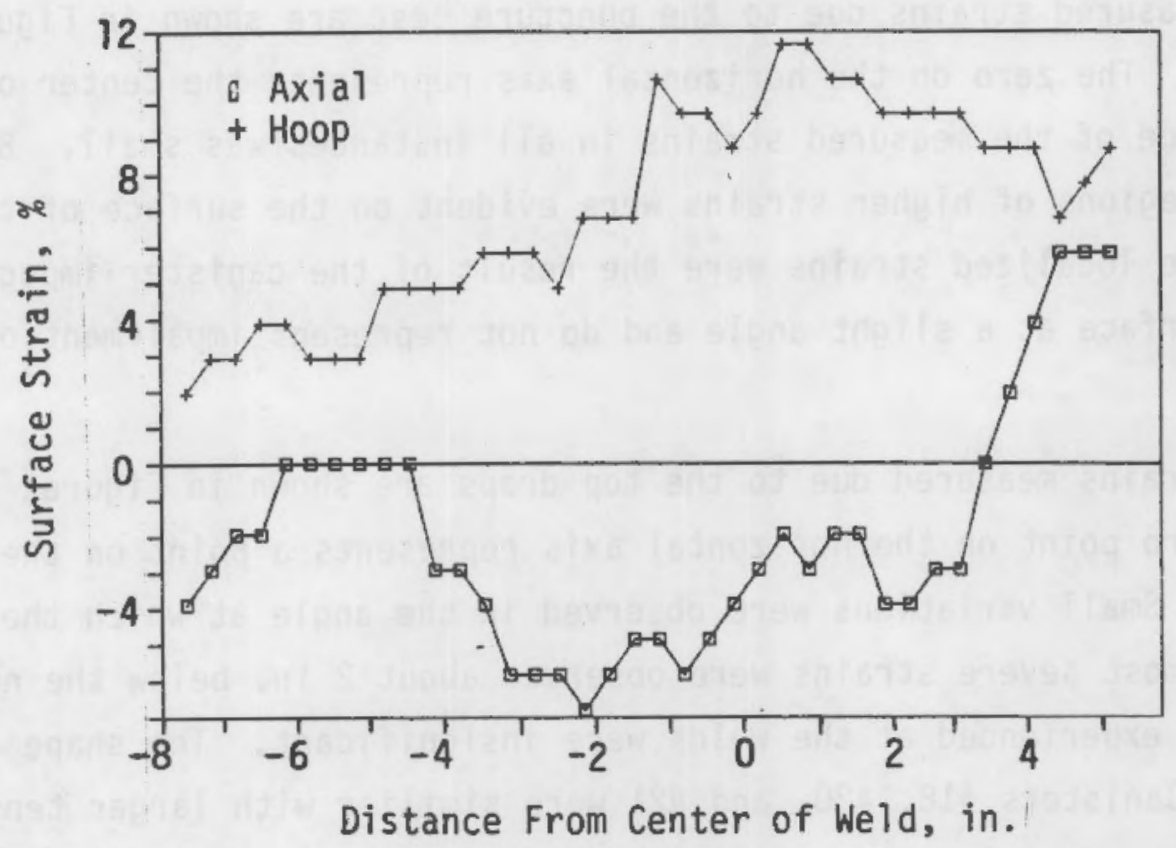

FIGURE 21. Surface Strain Along Axial Trace for Canister \#20 Bottom Drop

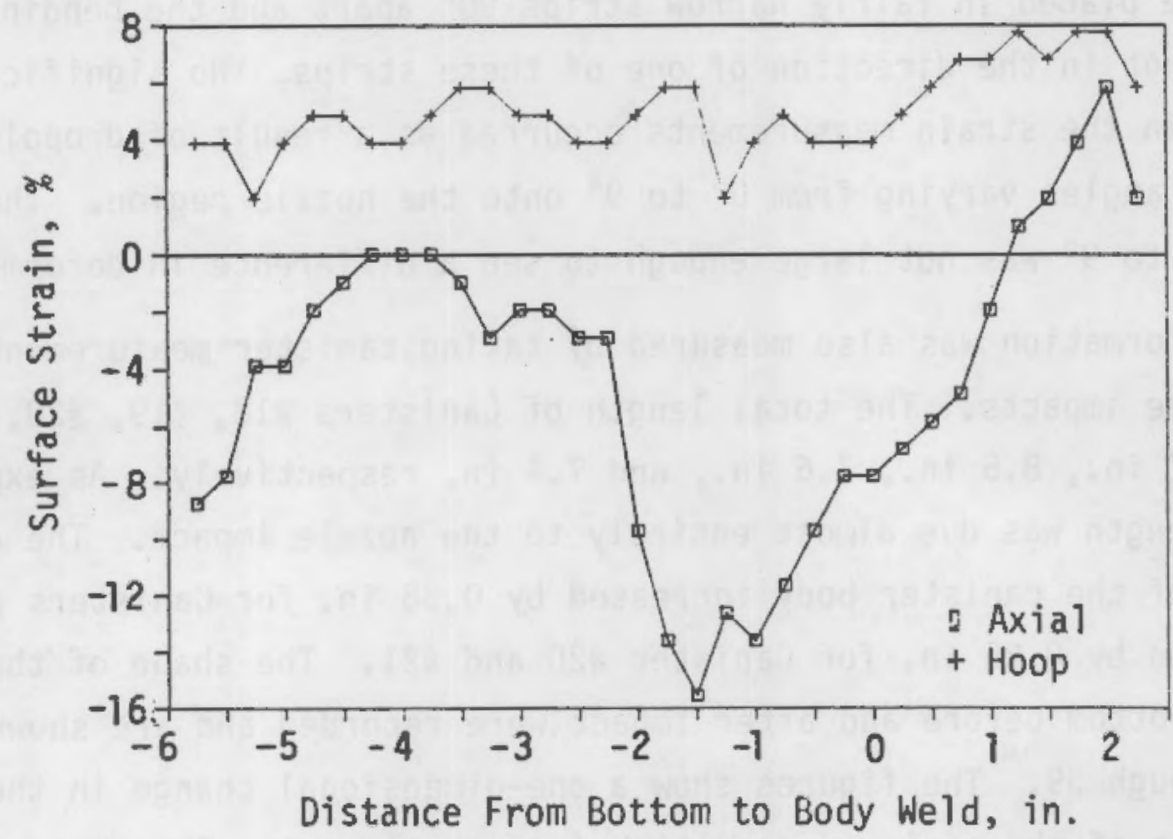

FIGURE 22. Surface Strain Along Axial Trace for Canister \#21 Bottom Drop 
The measured strains due to the puncture test are shown in Figures 23 through 27. The zero on the horizontal axis represents the center of impact. The magnitude of the measured strains in all instances was small. Some very localized regions of higher strains were evident on the surface of the canisters. These localized strains were the result of the canister impacting the cylinder surface at a slight angle and do not represent impairment of canister integrity.

The strains measured due to the top drops are shown in Figures 28 through 31. The zero point on the horizontal axis represents a point on the head to body weld. Small variations were observed in the angle at which the neck was bent. The most severe strains were observed about $2 \mathrm{in}$. below the neck weld. The strains experienced at the welds were insignificant. The shape of the curves for Canisters \#18, \#20, and \#21 were similiar with larger tensile axial strains and compressive hoop strains in the highly strained areas. Canister \#19 had larger tensile hoop strains and larger compressive axial strains. This variation was due to the location of the strain circles relative to the direction in which the nozzle bent. The strain circles on the top of Canister \#19 were placed in fairly narrow strips $90^{\circ}$ apart and the bending of the nozzle was not in the direction of one of these strips. No significant difference in the strain measurements occurred as a result of dropping the canister at angles varying from $0^{\circ}$ to $9^{\circ}$ onto the nozzle region. The small range of $0^{\circ}$ to $9^{\circ}$ was not large enough to see a difference in deformation.

The deformation was also measured by taking canister measurements before and after the impacts. The total length of Canisters $\# 18, \# 19, \# 20$, and \#21 changed by $7 \mathrm{in.,} 8.5 \mathrm{in.,} 7.6 \mathrm{in.,}$ and $7.4 \mathrm{in}$, respectively. As expected, the change in length was due almost entirely to the nozzle impact. The diameter of the bottom of the canister body increased by 0.38 in. for Canisters \#18 and \#19 and increased by $0.25 \mathrm{in}$. for Canister \#20 and \#21. The shape of the canister nozzle and bottom before and after impact were recorded and are shown in Figures 32 through 39. The figures show a one-dimensional change in the shape of these regions of the canister resulting from the impact. The shape of the midline region of the canister was not recorded due to the relatively small amount 
of deformation that occurred. The bottom impacts show a very localized deformation. All of the nozzles retracted approximately seven inches as a result of the impacts.

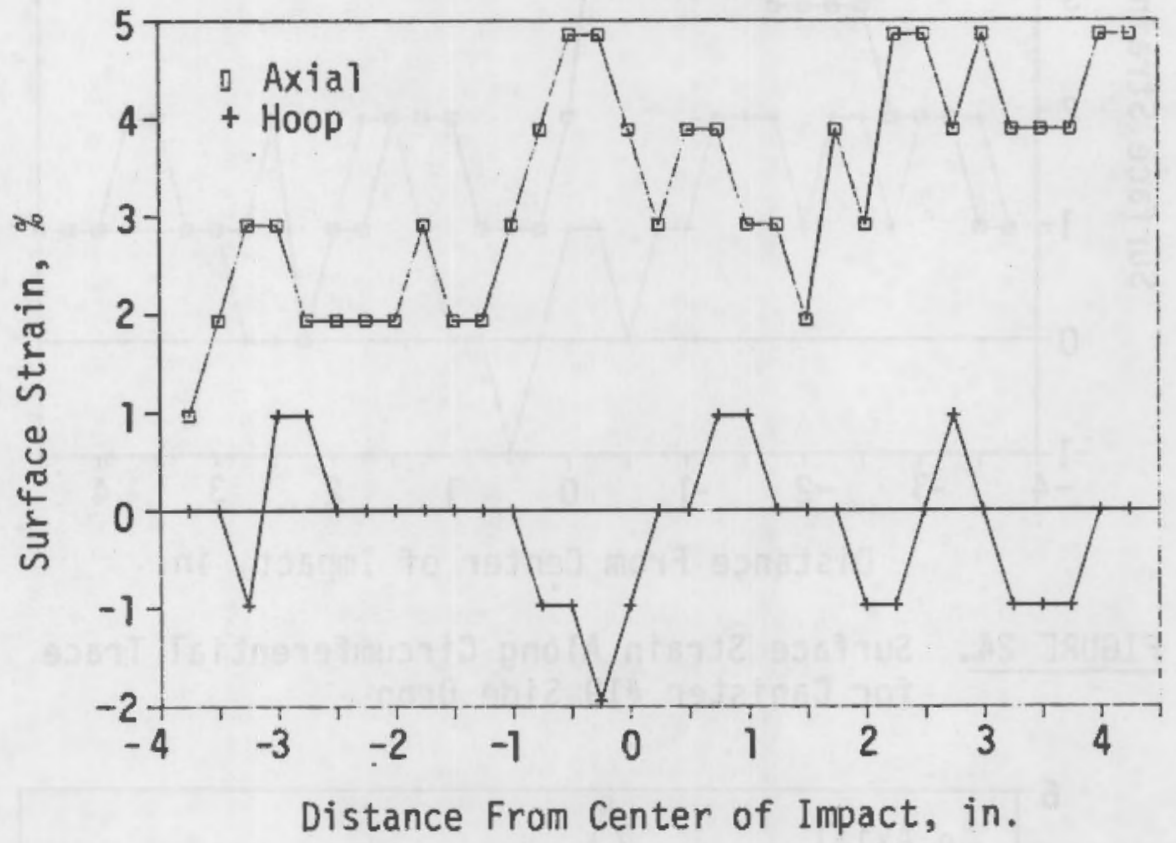

FIGURE 23. Surface Strain Along Axial Trace for Canister \#18 Side Drop 


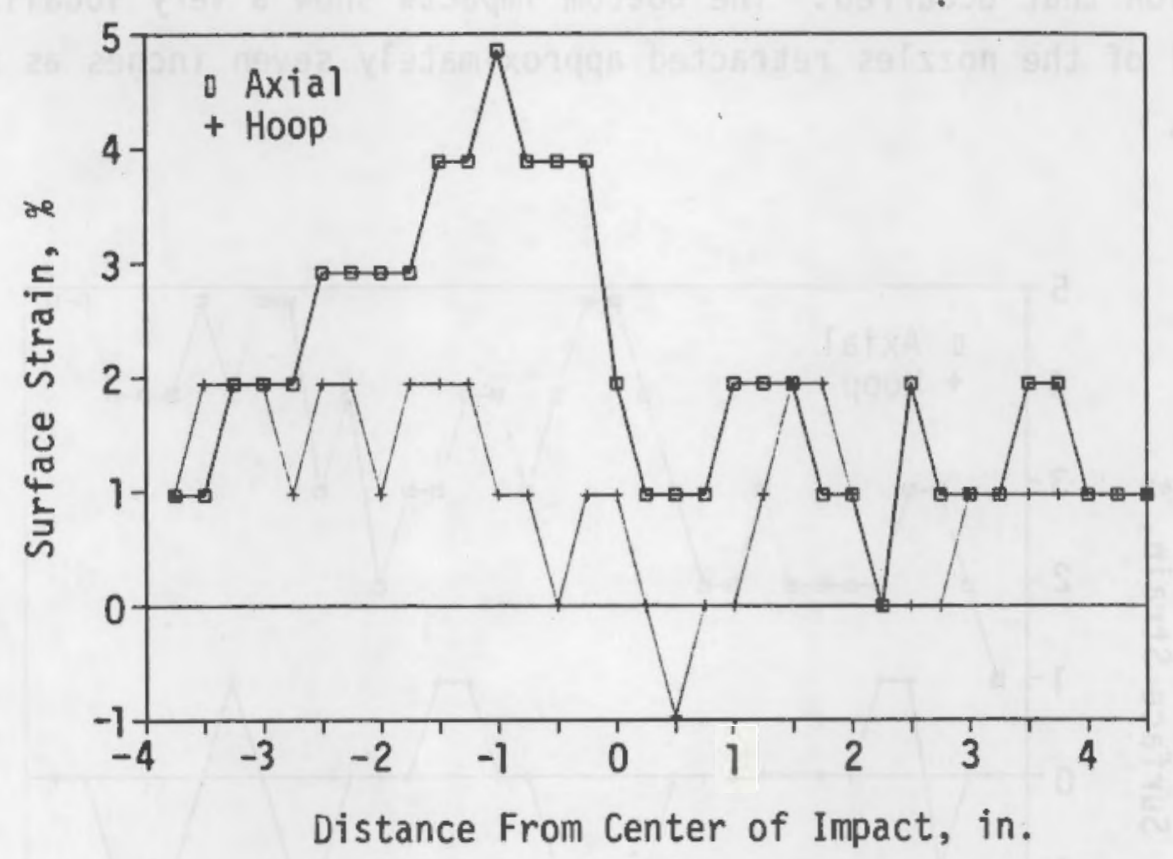

FIGURE 24. Surface Strain Along Circumferential Trace for Canister \#19 Side Drop

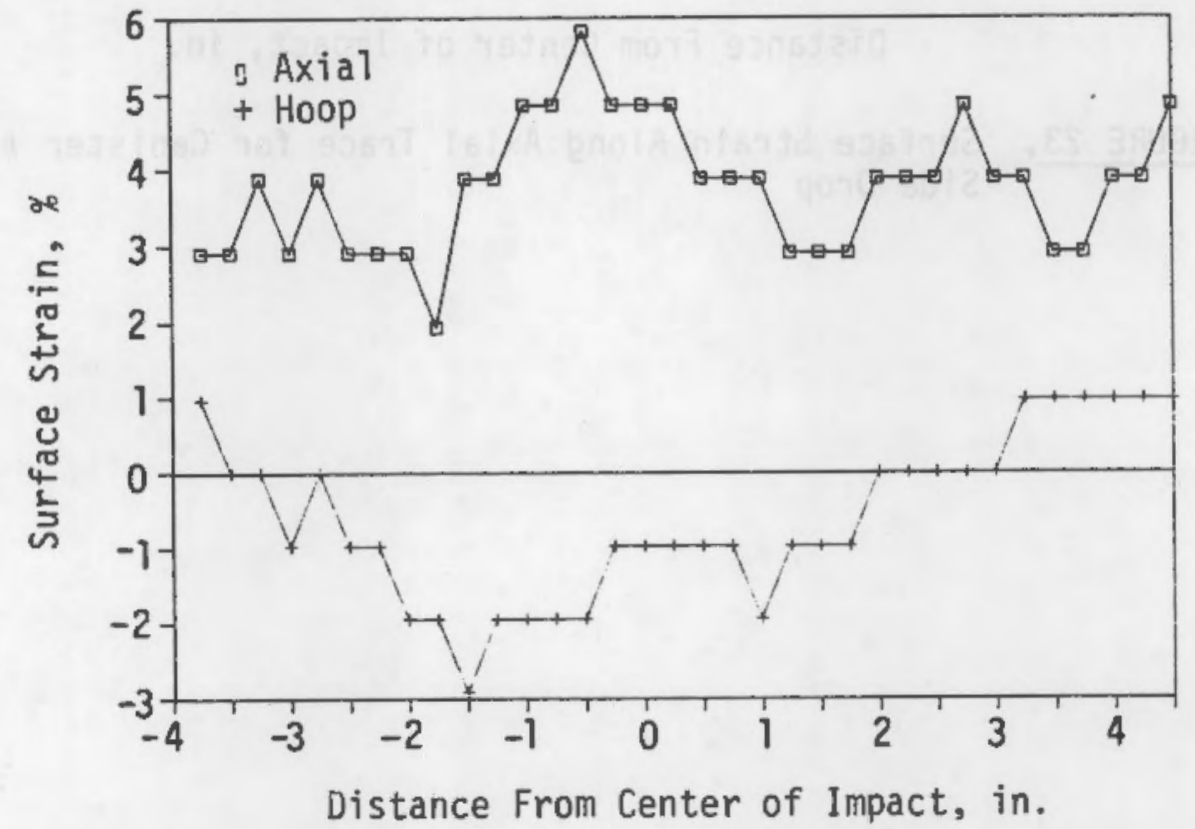

FIGURE 25. Surface Strain Along Circumferential Trace for Canister \#20 Side Drop 


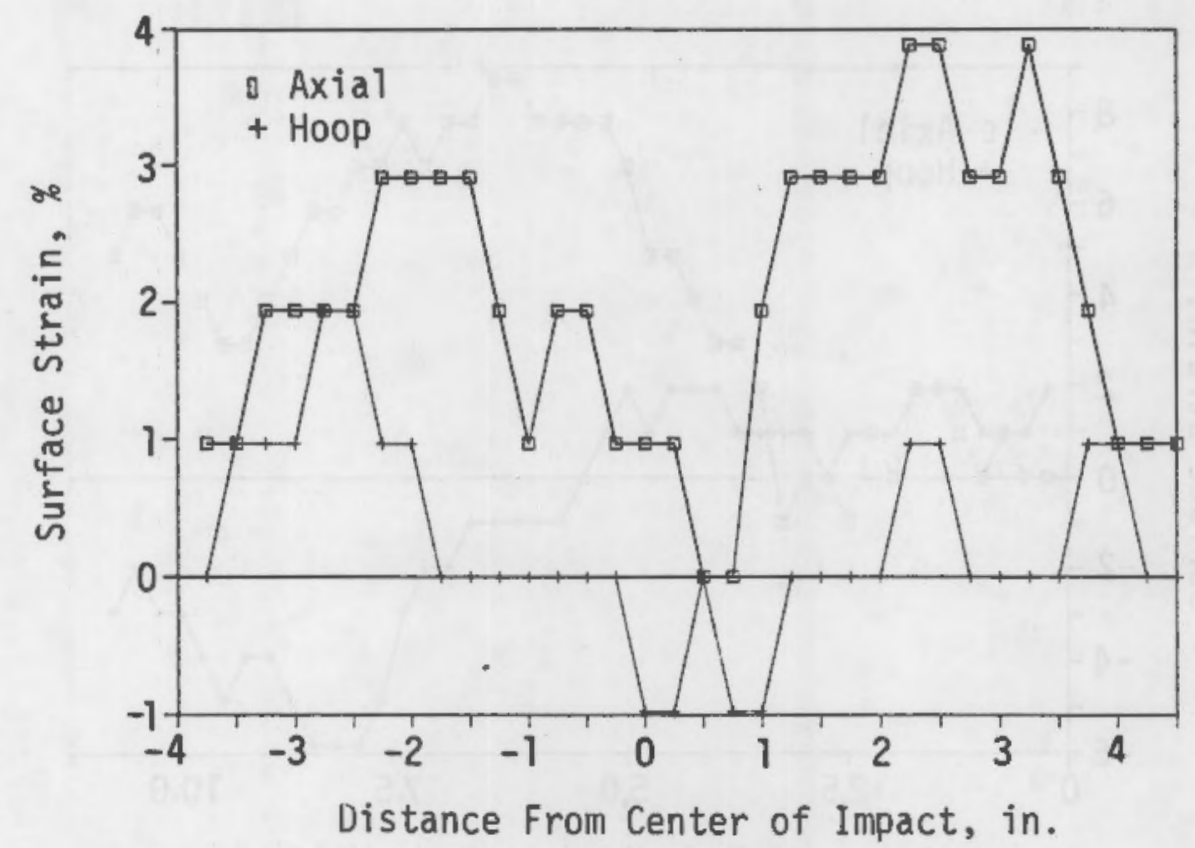

FIGURE 26. Surface Strain Along Axial Trace for Canister \#20 Side Drop

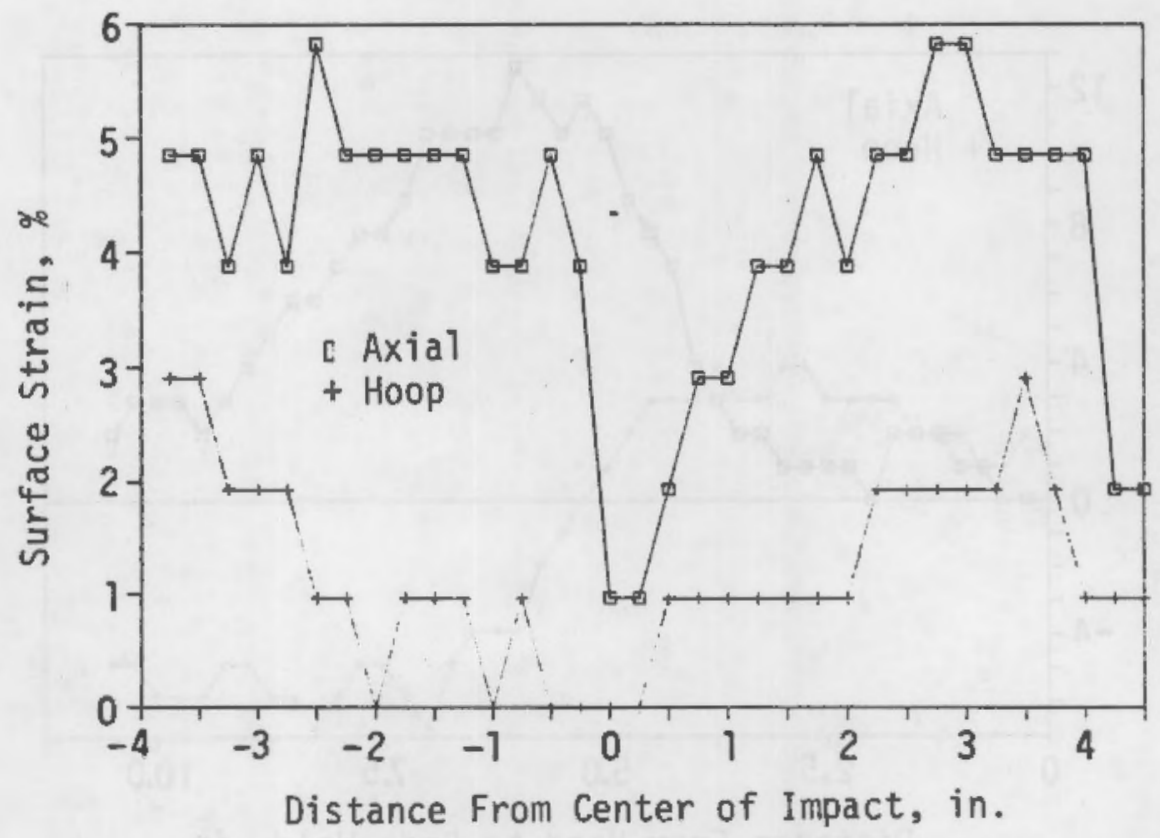

FIGURE 27. Surface Strain Along Axial Trace for Canister \#21 Side Drop 


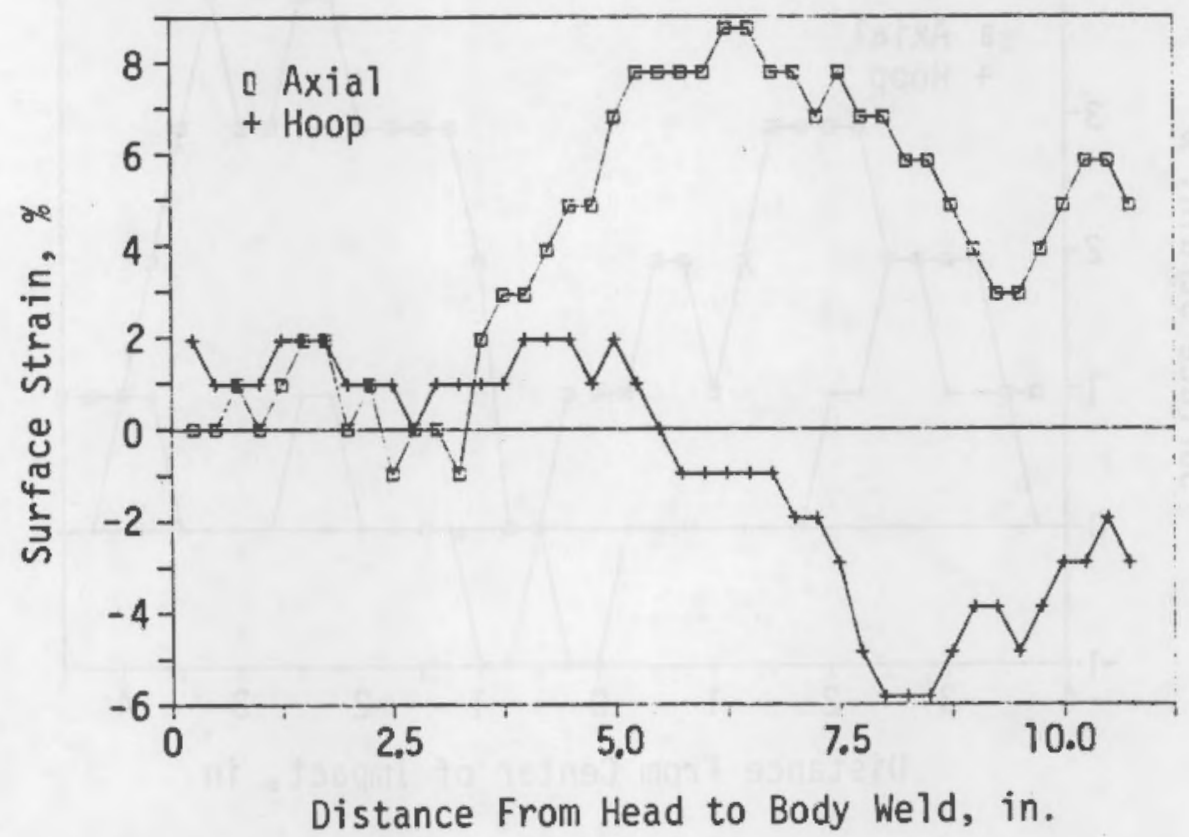

FIGURE 28. Surface Strain Along Axial Trace for Canister \#18 Top Drop

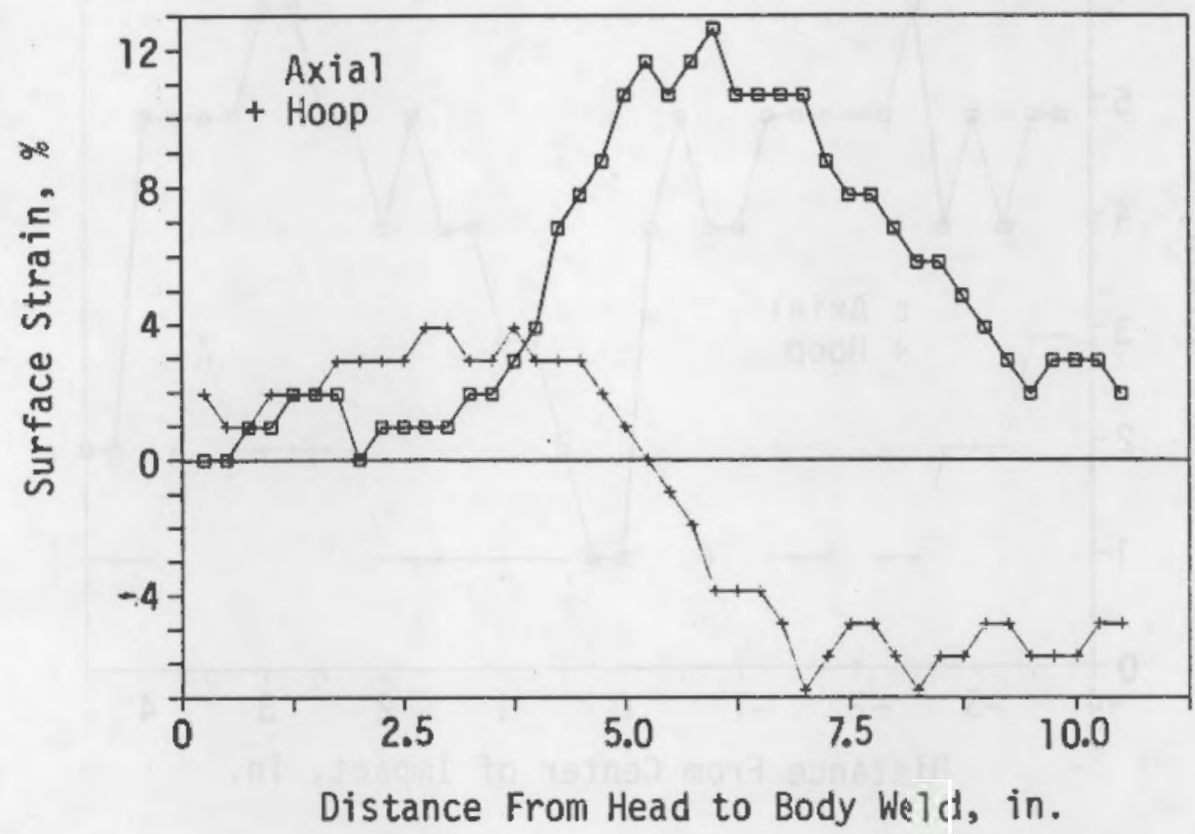

FIGURE 29. Surface Strain Along Axial Trace for Canister \#19 Top Drop 


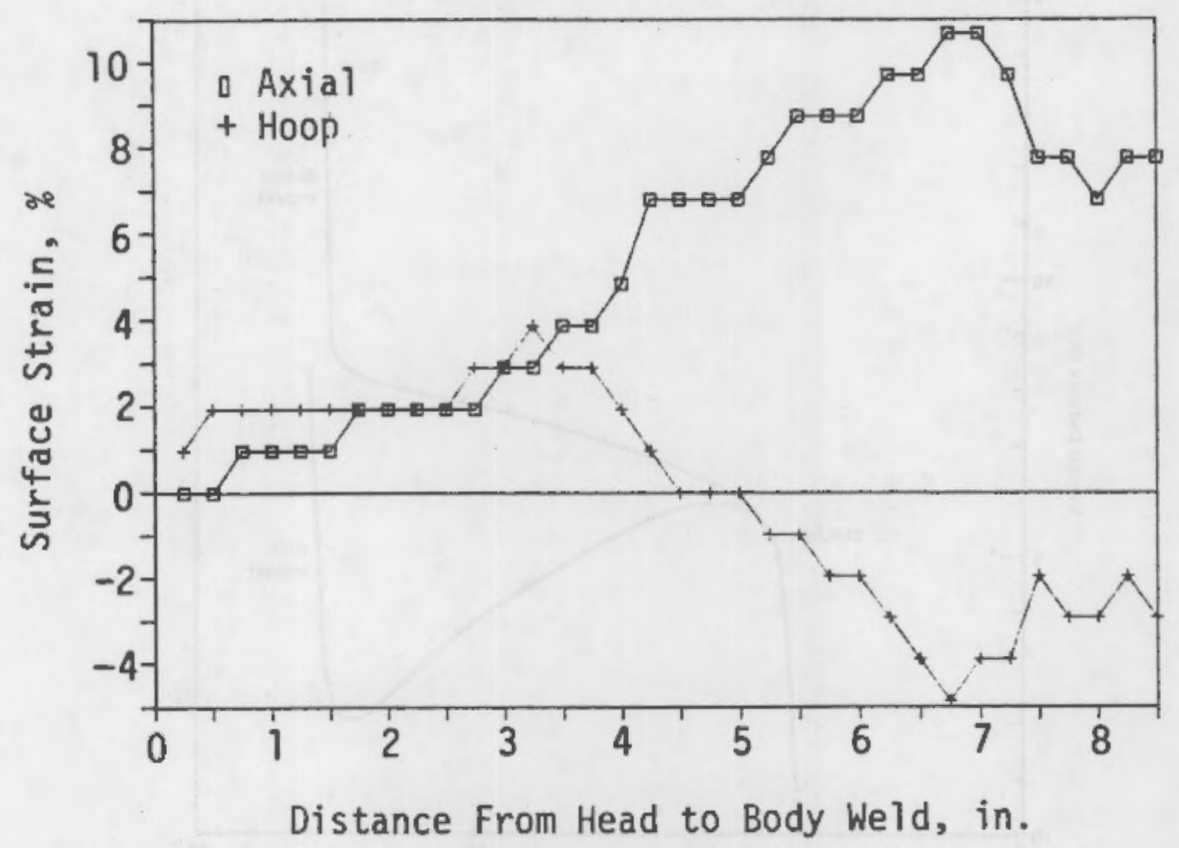

FIGURE 30. Surface Strain Along Axial Trace for Canister \#20 Top Drop

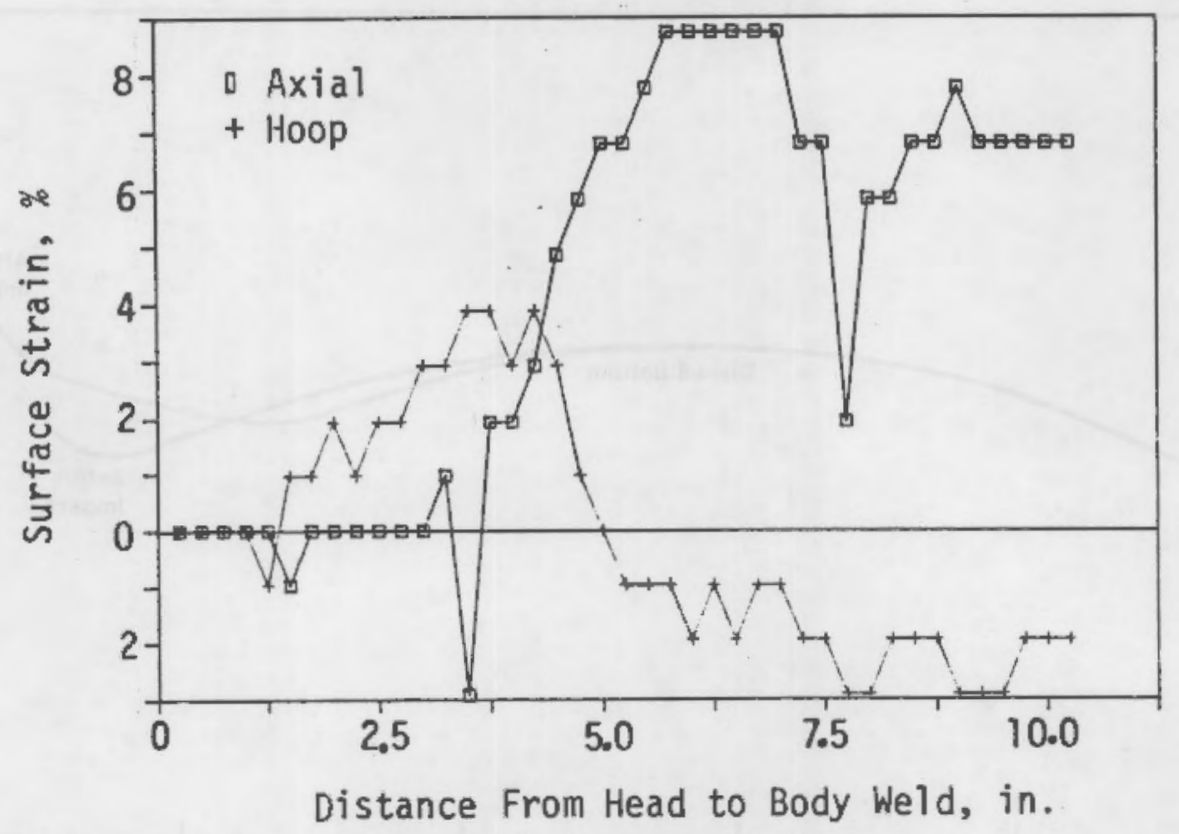

FIGURE 31. Surface Strain Along Axial Trace for Canister \#21 Top Drop 


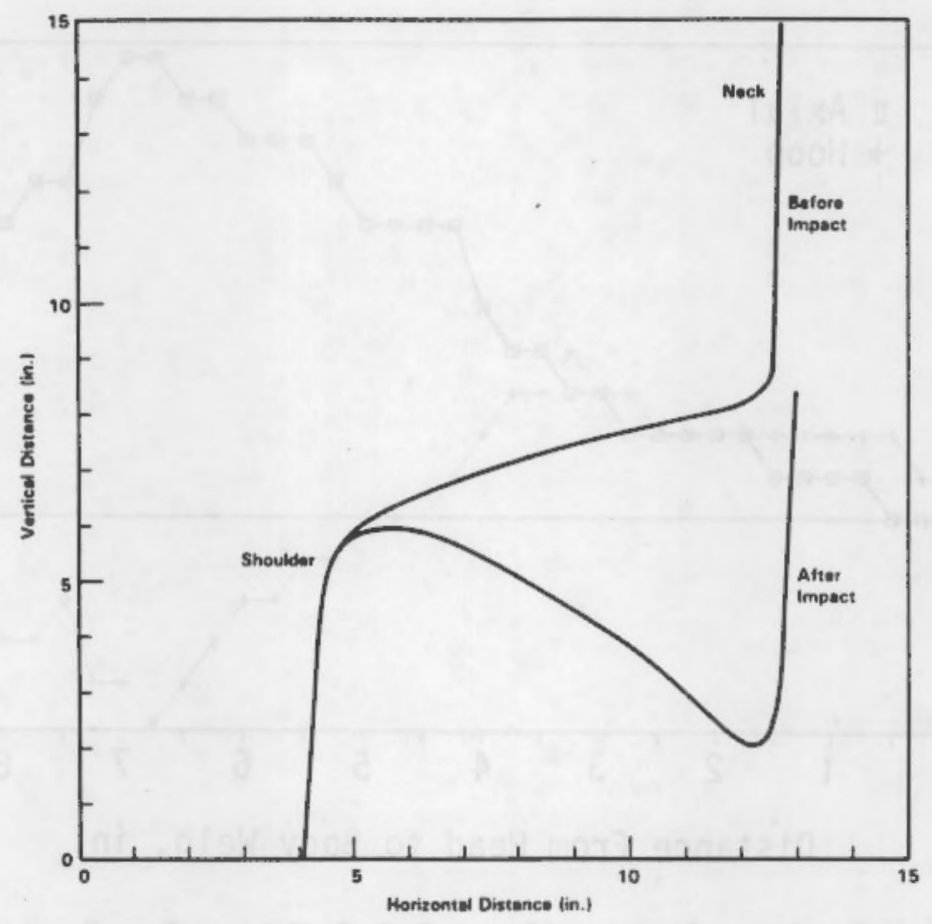

FIGURE 32. Shape of the Nozzle of Canister \#18

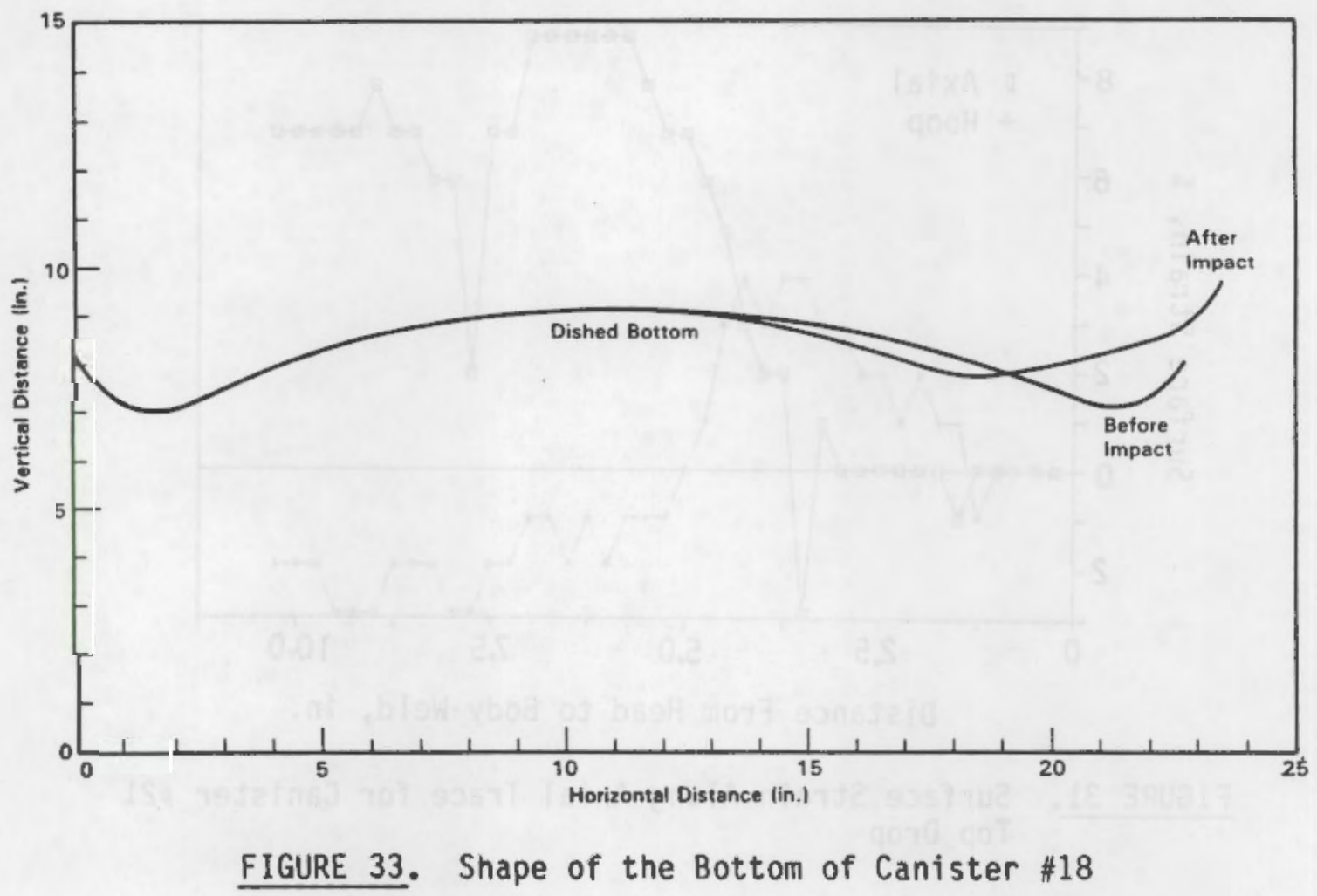




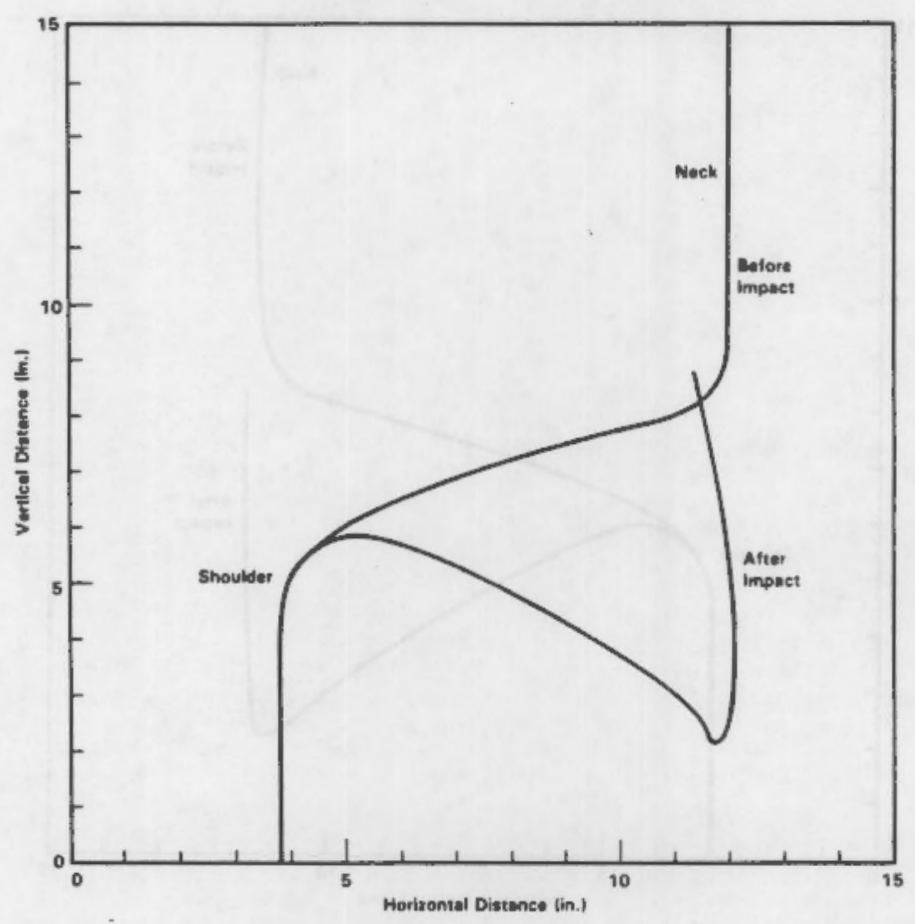

FIGURE 34. Shape of the Nozzle of Canister \#19

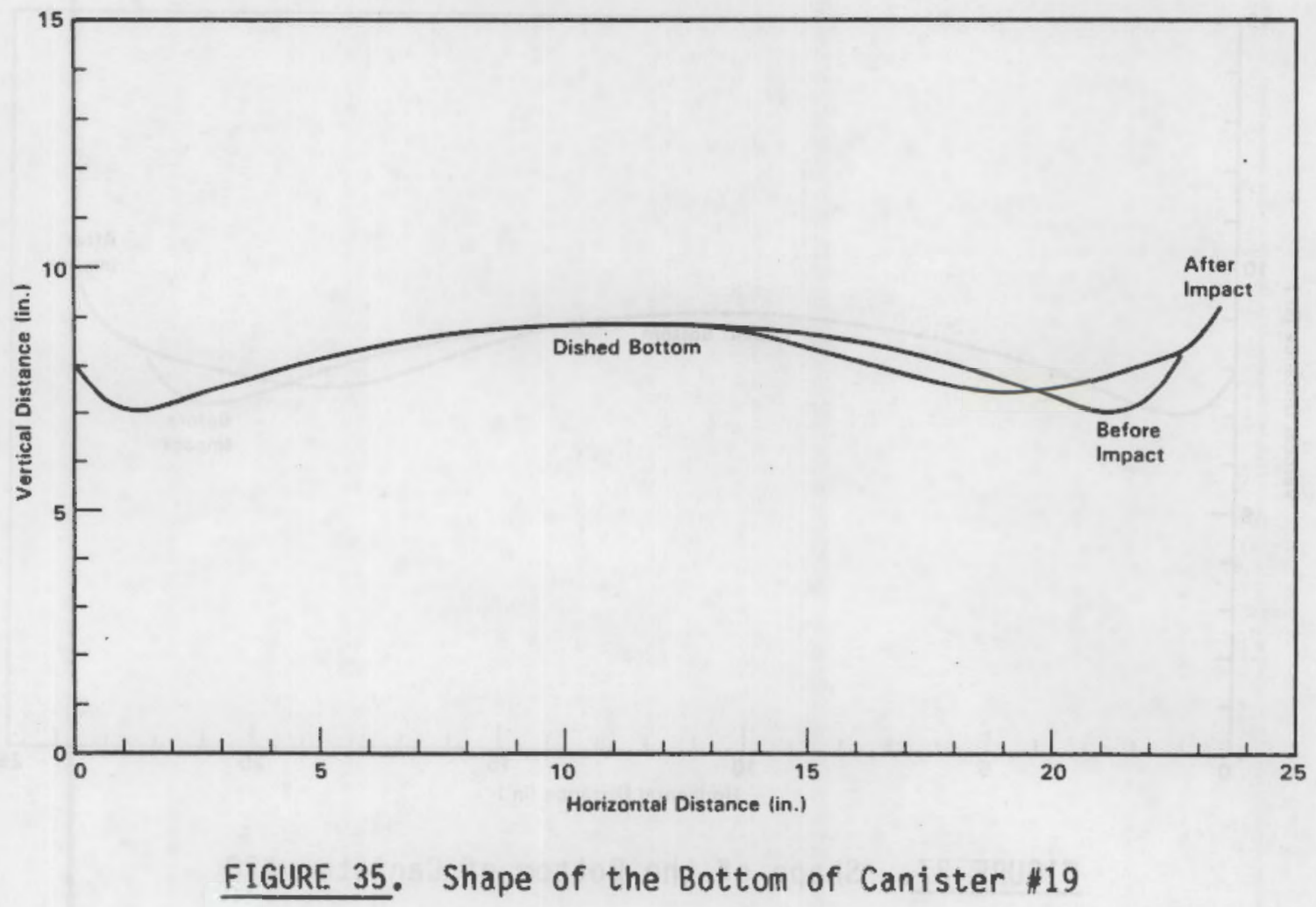




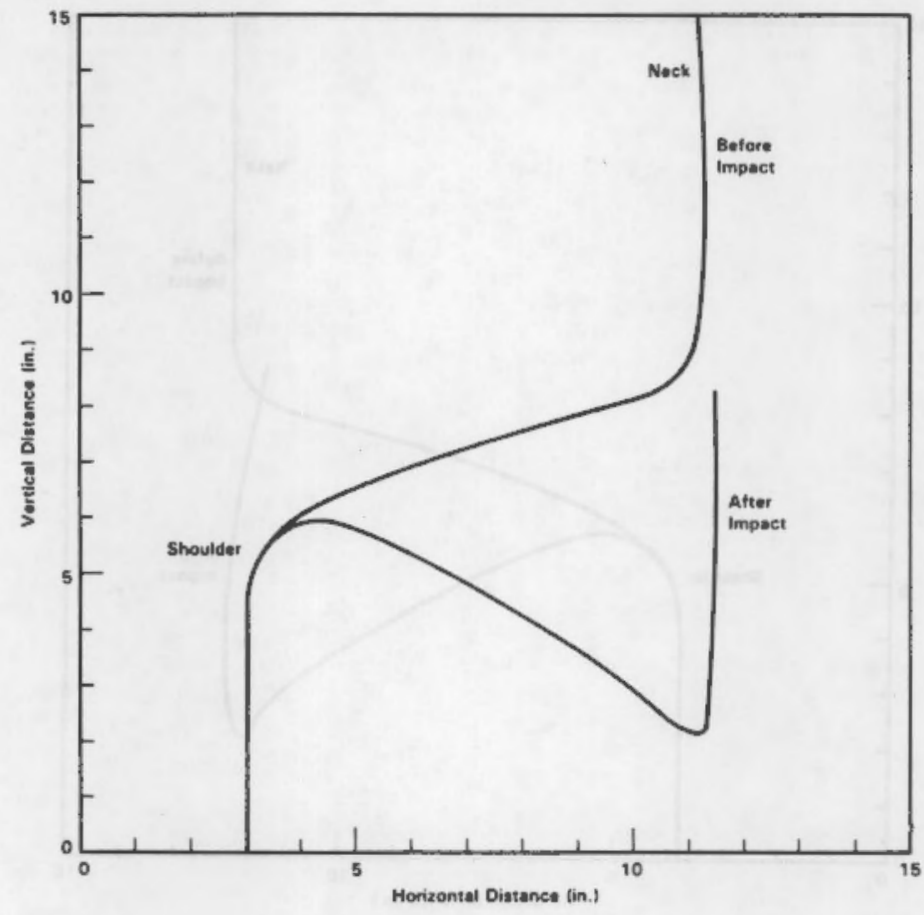

FIGURE 36. Shape of the Nozzle of Canister \#20

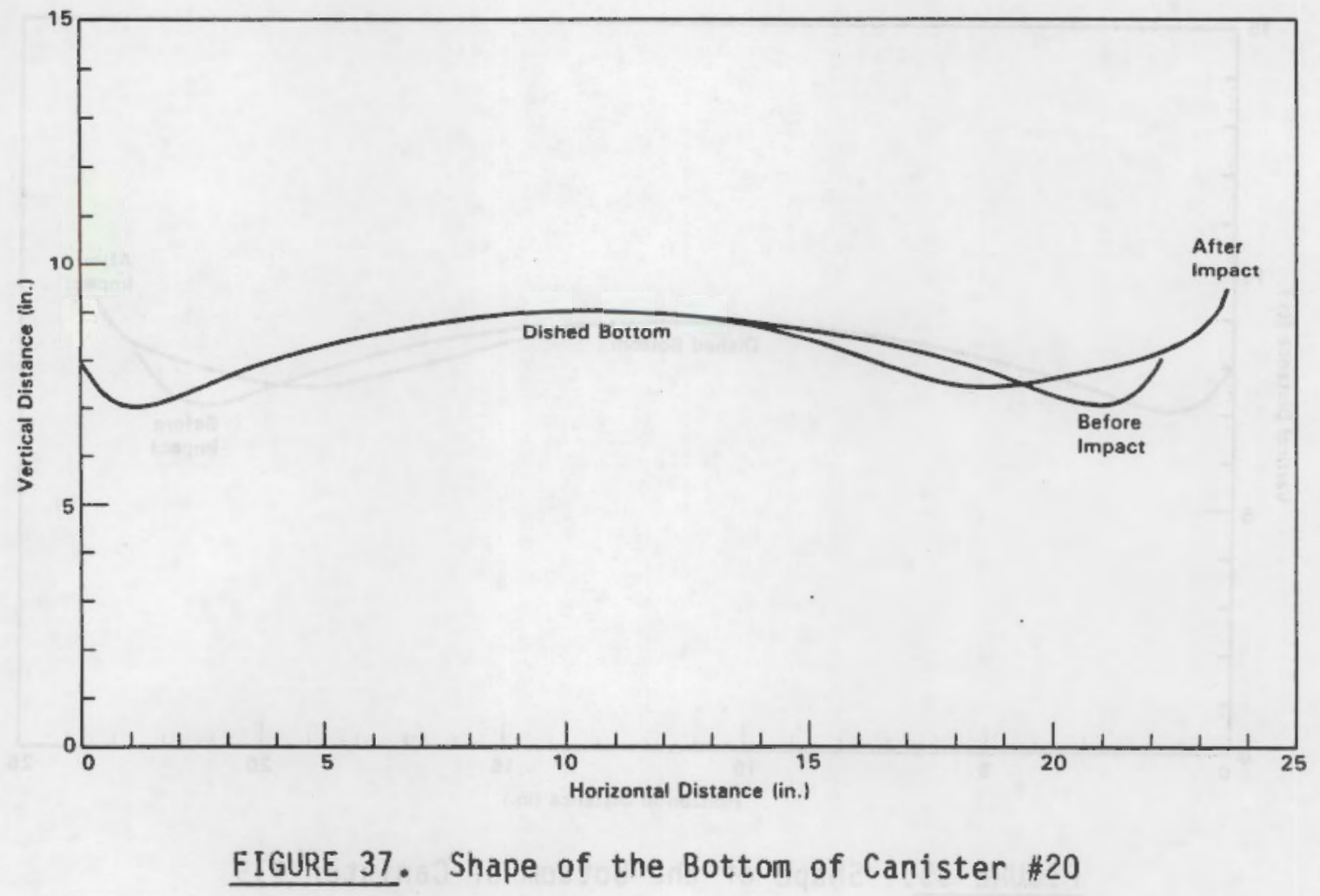




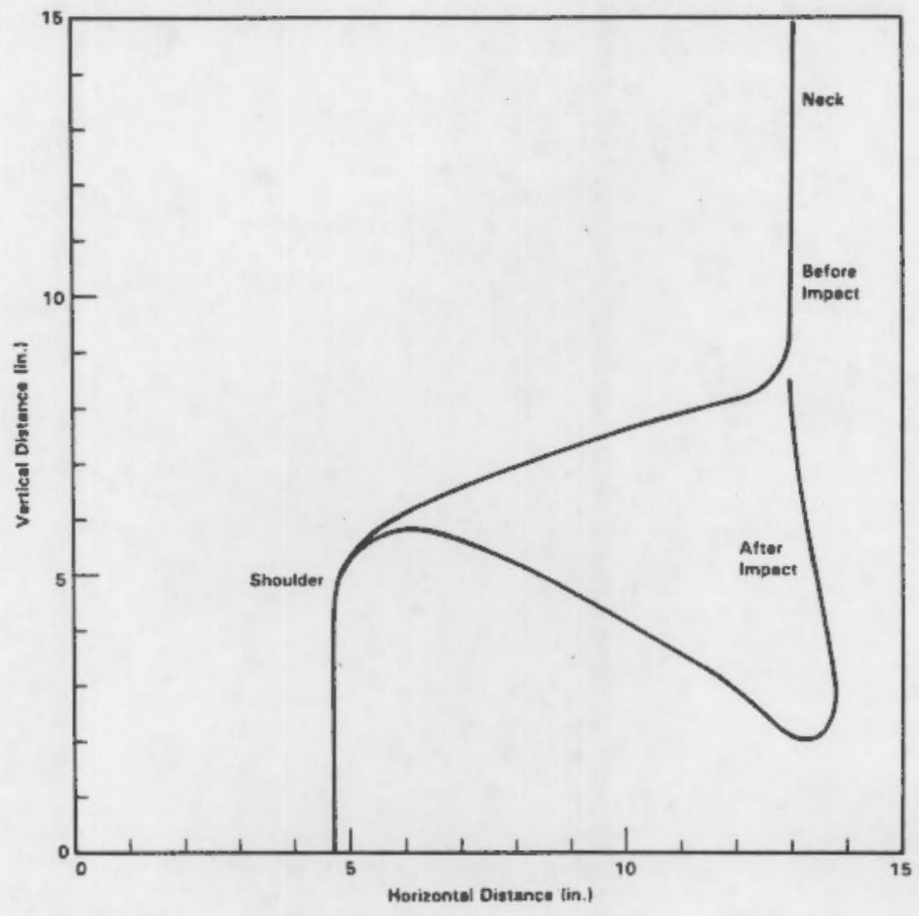

FIGURE 38. Shape of the Nozzle of Canister \#21

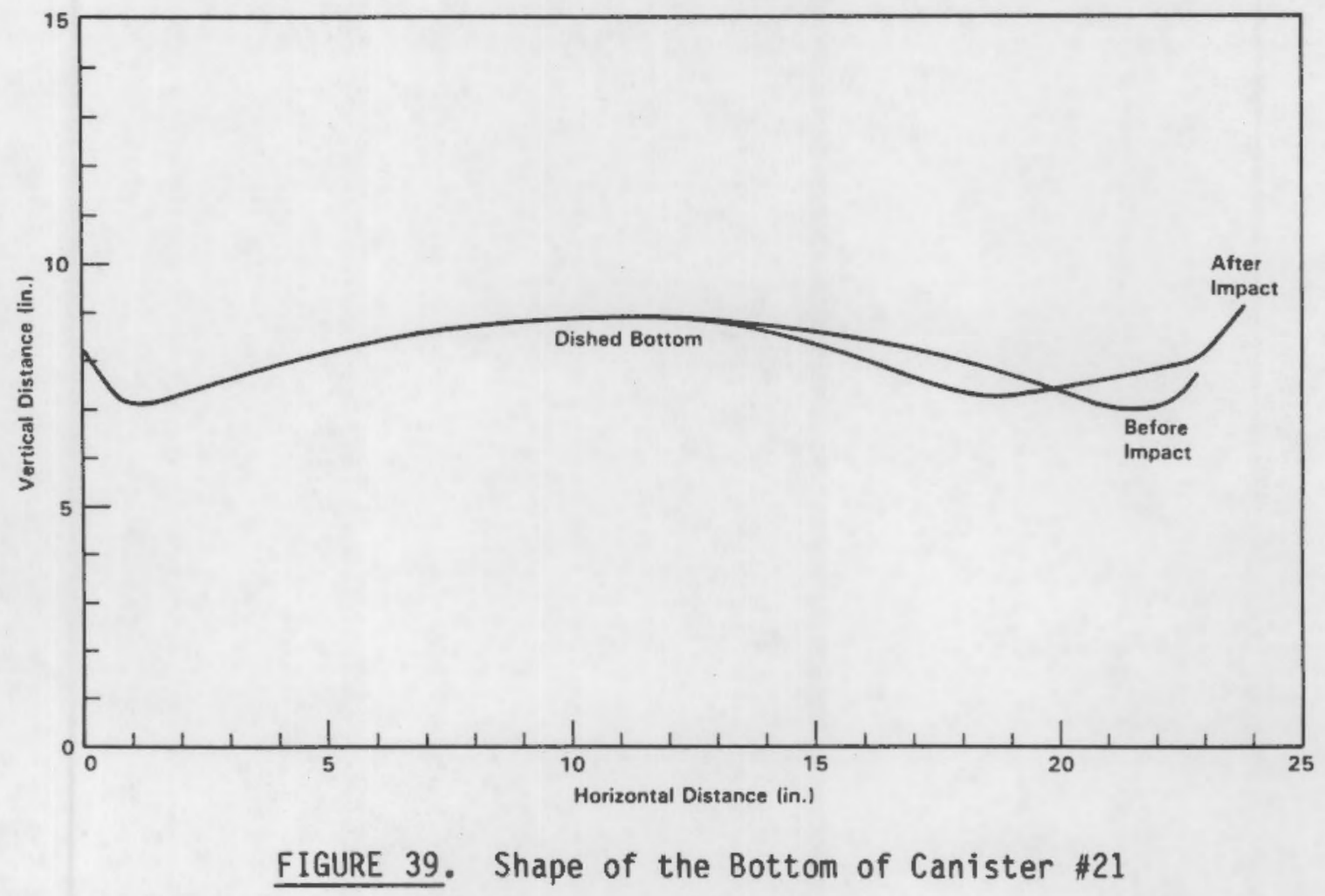




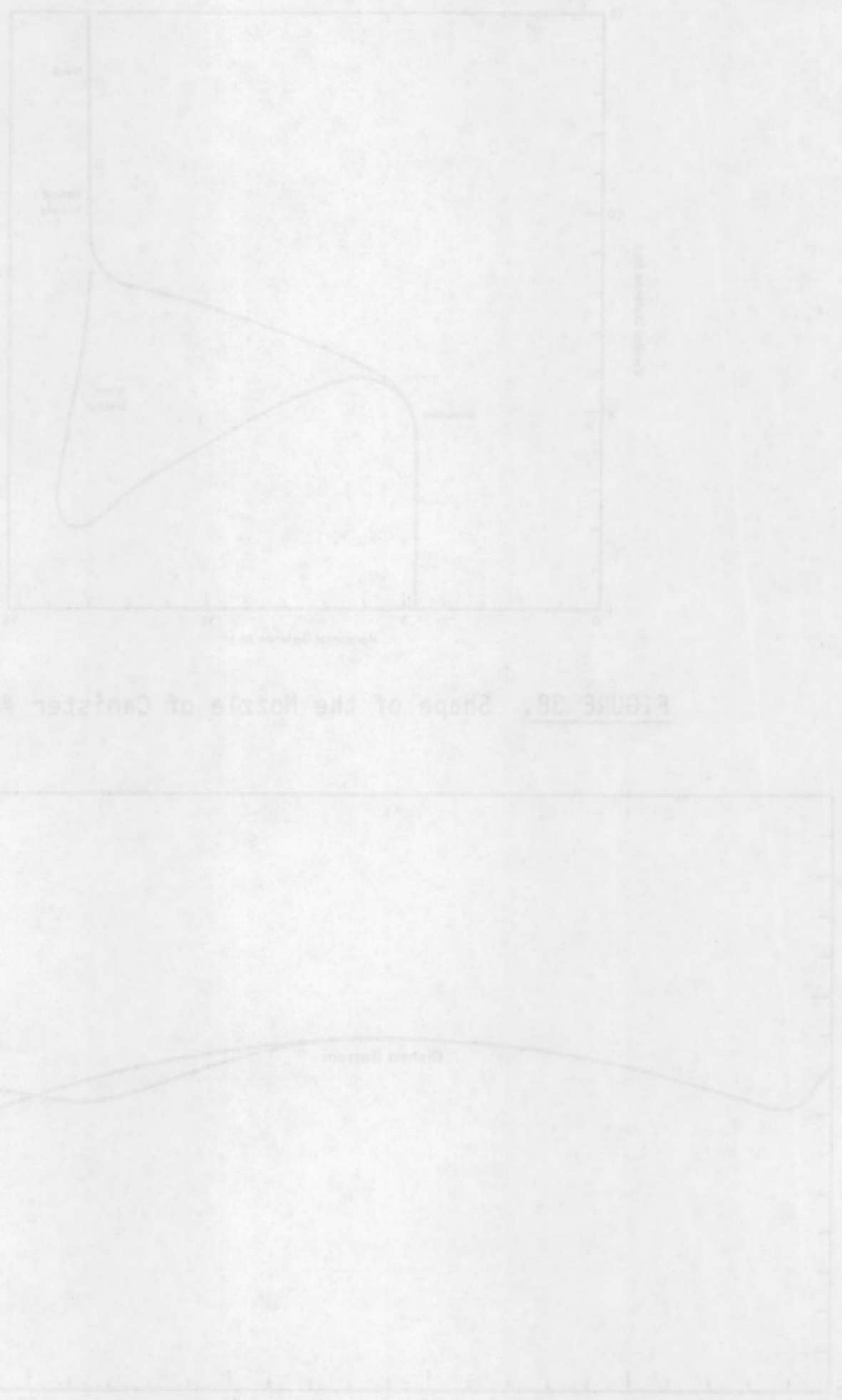




\subsection{REFERENCES}

Baxter, R. G. 1983. Description of Defense Waste Processing Facility Reference Waste Form and Canister. DP-1606, Rev. 1. Savannah River Laboratory, Aiken, South Carolina.

Cubberly, W. H. et al. 1978. Metals Handbook 9(3):409,757. ASM Handbook Committee, American Society for Metals, Metals Park, Ohio. 

DISTRIBUTION

No. of

Copies

OFFSITE

27 Technical Information Center

2 DOE Office of Defense Waste and Byproducts Management

GTN

Washington, DC 20545

ATTN: J. J. Jicha, DP-123

D. B. Leclaire, DP-12

2 EG\&G Idaho, Inc.

P.0. Box 1625

Idaho Falls, ID 83415

ATTN: R. Y. Maughn

R. M. Neilson, Jr.

3 E. 1. du Pont de Menours \& Co. Savannah River Laboratory

Aiken, SC 29801

ATTN: R. G. Baxter

E. J. Hennelly

J. N. Kelker

4 Sandia National Laboratory

Transportation Systems Development and Testing Division

Albuquerque, NM 87185

ATTK: G. Allen, Org. 6323

M. M. Madsen, Org. 6323

M. Molecke, Org. 6321

R. Sandeval, Org. 6321

2 J. Proietti

DOE Savannah River Operations Office

P.0. Box A

Aiken, SC 29801

E. L. Wilmot

DOE Sandia Laboratory Operations Office

Albuquerque, NM 87185

Beverly Rawles

BMI - Library

505 King Avenue

Columbus, $\mathrm{OH} 43210$
No. of

Copies

3 West Valley Nuclear Services Co., Inc.

P.0. Box 191

West Valley, NY 14171-0191

ATTN: C. C. Chapman

J. M. Pope

H. G. Richmond

J. D. Hurley

TWSO/Rocky Flats Plant

Rockwell International Corp.

P.0. Box 464

Golden, CD 80401

ONSITE

4 Richland Operations Office

E. A. Brachen

H. E. Ransom

M. L. Shupe

J. D. White

Rockwell Hanford Operations

N. A. Hertelendy

36 Pacific Northwest Laboratory

J. M. Alzheimer

H. F. Bonner

H. C. Burkholder

J. R. Carrell

T. D. Chikalla

J. R. Friley

L. K. Holton

R. F. Klein

J. L. McElroy

J. E. Mendel

M. D. Merz

J. E. Minor

M. E. Peterson (10)

P. A. Scott

S. C. Slate (5)

J. W. Thielman

Publishing Coordination (2)

Technical Information (5) 
